\title{
Osmanlı Saray Hekimliğinden Papalığın Hizmetinde İbranice Kitap Sansürcülüğüne Bir Yahudi Âlimin Hayat Hikâyesi: Domenico Yeruşalmî (ö. 1622) ve Sefer ha-Zikuk
}

The Life Story of a Jewish Scholar from a Physician of Ottoman Palace to Hebrew Book Censorship in the Service of the Papacy: Domenico Yerushalmi (d.1622) and Sefer ha-Zikuk

\section{Yasin Meral}

Doç. Dr., Ankara Üniversitesi İlahiyat Fakültesi

yasinmeral1979@gmail.com \& https://orcid.org/o0oo-0001-5794-721X

\begin{tabular}{|c|c|}
\hline $\begin{array}{l}\text { Makale Türü } \\
\text { Article Type }\end{array}$ & $\begin{array}{l}\text { Araştırma Makalesi } \\
\text { Research Article }\end{array}$ \\
\hline $\begin{array}{l}\text { Geliş Tarihi } \\
\text { Date Received }\end{array}$ & 07.11 .2021 \\
\hline $\begin{array}{l}\text { Kabul Tarihi } \\
\text { Date Accepted }\end{array}$ & 25.11 .2021 \\
\hline $\begin{array}{l}\text { Yayın Tarihi } \\
\text { Date Published }\end{array}$ & 31.12.2021 \\
\hline $\begin{array}{l}\text { Atıf } \\
\text { Citation }\end{array}$ & $\begin{array}{l}\text { Yasin Meral. "Osmanlı Saray Hekimliğinden Papalığın Hizmetinde İbranice } \\
\text { Kitap Sansürcülüğüne Bir Yahudi Âlimin Hayat Hikâyesi: Domenico } \\
\text { Yeruşalmî (ö. 1622) ve Sefer ha-Zikuk". Oksident 3/2 (2021): 105-134. }\end{array}$ \\
\hline $\begin{array}{l}\text { İntihal } \\
\text { Plagiarism }\end{array}$ & $\begin{array}{l}\text { Bu makale, Turnitin yazılımı ile taranmış ve intihal tespit edilmemiştir. } \\
\text { This article has been scanned by Turnitin and no plagiarism detected. }\end{array}$ \\
\hline Doi & https://doi.org/10.51490/oksident.1020299 \\
\hline
\end{tabular}




\section{Öz}

Katolik Kilisesi 16. yüzyllda Reform hareketlerine bir cevap olarak Hiristiyanllk inancı açısından sakıncalı görülen kitapların yasaklanması ve sansürden geçirilmesine önem göstermiştir. Bu çerçevede Index adı verilen listelerle yasaklı kitaplar ilan edilmeye başlanmış diğer taraftan da sansür komisyonlarl kurularak kitaplardaki sakıncalı ifadeler basılmadan önce çıkarılmış, basılanların da üzeri mürekkeple çizilmiştir. İtalya'nın farkl şehirlerinde sansür komisyonlarında genellikle Huristiyanliğ kabul eden Yahudi dönmeleri istihdam edilmiştir. Bunun temel sebebi, bu dönmelerin İbranice bilgileri ve Yahudi dinî literatürüne olan aşinalıklarıdır. Bu sansürcülerin başında da Domenico Yeruşalmî gelmektedir. 1555 yılında Kudüs'te doğan Domenico, 1578/91588/9 yullarl arasinda İstanbul'da Sultan III. Murad'in özel hekimi olarak görev yapmiştır. İstanbul'dan İtalya'ya giden Domenico, 1593 yllında Venedik'te Hiristiyan olmuştur. Domenico hem sansür kitabı hazırlamış hem de Yeni Ahit'i İbraniceye tercüme etmiştir. Domenico'dan günümüze gelen en önemli çalışma, sansür el kitabı olarak hazırladığ Sefer ha-Zikuk'tur. 1596 yilında Mantua'da sansür komisyonunda görevliyken hazırladığı bu eser, sansür tarihinin en ilginç örneklerinden biridir. Domenico, bu eserin girişinde sansürcüler için takip edilmesi gereken ilkeleri listelemektedir. Bu ilkelerde Horistiyanlığa yönelik tahkir ifadelerinin silinmesi veya değiştirilmesi belirtilmektedir. Ayrica reenkarnasyon gibi Kilise açısindan sapkın olarak kabul edilen düşünceler de bu listede yer almaktadir. Domenico, bu eserinde yüzlerce eserin isimlerini ve basildikları yerleri vererek hangi sayfa ve hangi satırdaki hangi kelimenin silineceğini belirtmektedir. Bazl eserler farkl basim yerleri dikkate alınarak tekrar edilmiştir. Domenico'nun sansürcü olarak imzasının yer aldığ pek çok eser günümüze ulaşmıştır. Bu eserler incelendiğinde Domenico'nun kendisinin belirlediği esaslara uymada titiz olmadiğr görülmektedir. Bu makalede Domenico'nun yaşam hikâyesi, Hiristiyan oluşu ve Sefer haZikuk'un içeriği hakkında bilgi verilecektir.

Anahtar Kelimeler: Domenico Yeruşalmî, sansür, İbranice, Papalık, Sefer ha-Zikuk, İstanbul, Venedik.

\section{Abstract}

In the $16^{\text {th }}$ century, in response to the Reform movements, the Catholic Church emphasized banning and censoring books deemed objectionable in Christianity. In this framework, banned books were announced with lists called Index; on the other hand, censorship commissions were established, offensive statements in the books were removed before they were printed, and the printed ones were scratched out with ink. In censorship commissions in different cities of Italy, the employees were generally Jews who converted to Christianity. The main reason for this is their knowledge of Hebrew and their familiarity with Jewish religious literature. Domenico Yerushalmi is one of these censors. Born in Jerusalem in 1555, Domenico lived in Istanbul between the years 1578/9-1588/9. He served as Sultan Murad's private physician. Domenico, who went to Italy from Istanbul, converted to Christianity in Venice in 1593. He both prepared a censorship book and translated the New Testament into Hebrew. The most significant work of Domenico is Sefer ha-Zikuk, prepared as a censorship handbook. This work, which he prepared while he was on the censorship commission in Mantua in 1596, is one of the most interesting examples in the history of censorship. In the introduction to this work, Domenico lists the principles for censors. These principles specify the deletion or modification of insulting statements against Christianity. In addition, thoughts considered heretical for the Church, such as reincarnation, are also included in this list. In this work, Domenico gives the names of hundreds of Hebrew works and the places they were printed, indicating which word on which page and which line will be deleted. Some works have been repeated considering different publication places. Many works that include Domenico's signature as a censor have survived. When these works are examined, it is seen that Domenico was not meticulous in complying with the principles set by himself. Giving information about the life story of Domenico and his conversion to Christianity, this article examines the content of Sefer haZikuk.

Keywords: Domenico Yerushalmi, censor, Hebrew, Catholic Church, Sefer ha-Zikuk, İstanbul, Venice. 


\section{Özet}

16. yüzyıl Katolik Kilisesi açısından en sıkıntılı yüzyıllardan biridir. Martin Luther'in Reform hareketini başlatması, Kilise için birçok sorunu da beraberinde getirmiştir. Reform hareketine karşı Kilise kendi içerisinde Karşı-Reform adı verilen bir dizi uygulama başlatmıştır. Bunlardan biri de Hıristiyanlık inancı açısından sakıncalı görülen kitapların yasaklanması ve bazılarının da sansürden geçirilmesidir. Kilise'nin heretiklere karşı mücadelesinden Yahudi dinî literatürü de nasibini almıştır. Yahudiliğin en önemli kitaplarından Talmud, Kilise tarafindan yasaklanmış ve sıkça toplatılarak yakılmıştır. Talmud dışında kalan literatürün ise sansürden geçirilmesi şartıyla bulundurulmasına izin verilmiştir. Papalığın etkili olduğu İtalya'nın farklı şehirlerinde sansür komisyonları kuran engizisyon kurumu, bu komisyonlarda genellikle Hıristiyanlığ kabul eden Yahudi dönmelerini istihdam etmiştir. Bunun temel sebebi, genellikle eski hahamlardan oluşan bu dönmelerin İbranice bilgileri ve Yahudi dinî literatürüne olan aşinalıkları sebebiyle İbranice kitaplardaki Hıristiyanlıkla ilgili sakıncalı yerlerin tespitinde daha avantajlı konumda olmalarıdır. Papalığın hizmetinde sansürcü olarak çalışan Yahudi dönmelerinden birisi de Domenico Yeruşalmî'dir. 1555 yılında Kudüs'te İspanya kökenli bir ailenin çocuğu olarak doğan Domenico, Filistin'in kuzeyindeki Celile bölgesinde din eğitimi almıştır. Genç yaşlarında muhtemelen saraydaki diğer Yahudi doktorların tavsiyesiyle İstanbul'a gelen Domenico, yaklaşık 1578/9-1588/9 yılları arasında İstanbul'da sultanın özel hekimi olarak görev yapmiştır. İstanbul'dan İtalya'ya geçen Domenico, 1593 yılında Venedik'te Hıristiyanlığ 1 benimsemiştir. Domenico'nun hem sansür kitabı hazırlaması hem de Yeni Ahit'i İbraniceye tercüme etmesi hem de Yahudilere yönelik reddiye kaleme alması

\section{Summary}

The $16^{\text {th }}$ century was one of the most troubled centuries for the Catholic Church. Luther's Reformation movement brought many problems for the Papacy. Against the Reform movement, the Church initiated a series of reforms called CounterReformation. One of these is the banning of books considered heretical in Christianity and the censorship of some of them. Jewish religious literature has also taken its share from the struggle of the Church against heretics. The Talmud, one of the most important books of Judaism, was banned by the Church and was frequently confiscated and burned. Literature other than the Talmud is permitted if it is censored. Establishing censorship commissions in different cities of Italy, where the Papacy was influential, the inquisition generally employed Jewish converts who accepted Christianity in these commissions. The main reason for this is that these converts, who usually were old rabbis, are more advantageous in determining where they have problems with Christianity in Hebrew books due to their knowledge of Hebrew and their familiarity with Jewish religious literature. One of the Jewish converts working as a censor in the service of the Papacy is Domenico Yerushalmi. Born in Jerusalem in 1555 to a family of Spanish origin, Domenico studied religion in the Galilee region of northern Palestine. Domenico, who came to Istanbul at a young age, probably on the advice of other Jewish physicians in the palace, served as the sultan's private physician in Istanbul between about 1578/9-1588/9. Passing from Istanbul to Italy, Domenico adopted Christianity in Venice in 1593. Domenico's preparation of a censorship book, his translation of the New 
onun bu konudaki kararlılığını göstermesi açısından önem arz etmektedir. Domenico, Huristiyan olduktan sonra Kilise yetkilileri tarafından İbranice kitapların sansür komisyonlarında istihdam edilmiştir. Onun ilk görev yeri Mantua'dur. Domenico, 1595-1605 yllları arasında Mantua'da yüzlerce kitabın sansür işlemlerini yapmiştır. Domenico'nun Ferrara, Milan ve Roma gibi İtalyan şehirlerinde bu işleri yürüttüğü bilinmektedir. Hayatının son dönemlerini Roma'da Neofiti Koleji'nde İbranice öğreticiliği ve sansür işleriyle sürdüren Domenico, 1622 yılında Roma'da hayatını kaybetmiştir. Roma'dayken İstanbul izlenimlerini anlattığı Relatione della Gran Citta di Costantinopli adlı eserini kaleme almıştır. Domenico'nun bu eseri beş bölümden oluşmaktadır. İlk bölümde şehrin kapıları, çeşmeler, camiler, saraylar, dükkânlar, yabancılar için kurulan hanlar, hastaneler, medreseler, vadiler, hamamlar ve meydanlar gibi yapılar yer almaktadır. Domenico bu bölümde şehrin yedi tepe üzerinde kurulduğundan, Yedikule zindanlarından, Ayasofya camiinden ve diğer selatin camilerinden, kiliselerden ve sinagoglardan da bahsetmektedir. İkinci bölümde şehirdeki idari, hukuki sistemden ve vergilerden bahsedilmektedir. $\mathrm{Bu}$ bölümde ayrıca medreseler, hocalar, şeyhler, kadılardan söz edilmektedir. Üçüncü bölümde sultanın yaşadığı saraydan ve diğer kullandığ 1 saraylardan bahsetmektedir. Divan toplantılarından ve bu toplantılara katılan kazasker, defterdar, yeniçeri ağası ve beylerbeyi gibi devlet erkânına değinilmektedir. Dördüncü bölümde sultanın günlük hayatı hakkında detaylı bilgiler verilmektedir. $\mathrm{Bu}$ bölümde sultanın şehirde gezmek istediğinde maiyetindekilerle birlikte nasıl dolaştığını, sabah namazına nasıl kalktığını, kahvaltıda neler yediğini, haremdeki kadınlarla iletişimini, sultanın
Testament in Hebrew, and his refutation against the Jews are important in showing his determination to embrace Christianity. After Domenico became a Christian, he was employed by Church officials on censorship commissions of Hebrew books. His first assignment is Mantua. Between 1595 and 1605, Domenico censored hundreds of books in Mantua. It is known that Domenico carried out these works in Italian cities such as Ferrara, Milan, and Rome. Domenico, who spent the last years teaching Hebrew and censorship at Neofiti College in Rome, died in Rome in 1622. While in Rome, he wrote his work called Relatione della Gran Citta di Constantinopli, in which he describes his impressions of Istanbul. This work of Domenico consists of five parts. The city's gates, fountains, mosques, palaces, shops, inns established for foreigners, hospitals, madrasas, valleys, baths, and squares are depicted in the first part. Within this very part, Domenico also mentions the city's foundation on seven hills, the Yedikule dungeons, the Hagia Sophia mosque and other great mosques, churches and synagogues. The city's administrative, legal system, and taxes are mentioned in the second part. This part also speaks of madrasahs, hodjas, sheiks, and qadis. In the third part, he talks about the palace where the sultan lived and the other palaces he used. Court meetings and state officials such as kazasker, treasurer, janissary aghas, and beylerbeyi are also mentioned in this part. In the fourth part, detailed information about the sultan's Daily life is given. This part explains how the sultan walked around the city with his entourage, how he got up for the morning prayer, what he ate for breakfast, his communication with the women in the harem, and the sultan's 
şeyhülislam ve hocasıyla olan hukukunu anlatmaktadır. Bölümde ayrıca Ramazan ve Kurban bayramlarından, yağmur duasından, veba zamanlarından, köpeklerin itlaf edilmesinden ve Türkler arasında kedi sevgisinden bahsedilmektedir. Beşinci bölümde ise genel anlamda İslam ile ilgili bilgiler verilmektedir. Dört mezhep, İranlılarla Türkler arasındaki inanç farklılıkları, abdest, namaz, cami adabı, Cuma namazları, sünnet, cihad, sadaka, hac ibadeti, tevhid inanışı, peygamberlik inancı gibi hususlara bu bölümde yer verilmektedir. Domenico'nun günümüze gelen en büyük mirası, sansür el kitabı olarak hazırladığı Sefer ha-Zikuk'tur. 1596 yılında Mantua'da sansür işleriyle ilgilenirken hazırladığı bu eser sansür tarihinin en ilginç kayıtlarından birisi olarak karşımızda durmaktadır. Domenico, bu eserin girişinde sansürcüler için takip edilmesi gereken temel ilkeleri listelemektedir. $\mathrm{Bu}$ liste incelendiğinde Hıristiyan inancına yönelik hakaret içeren ifadelerin silinmesi veya değiştirilmesi en önemli gündem maddesidir. Bunun dışında reenkarnasyon, cinler, kötü ruhlar ve bunlarla ilgili batıl inanış ve uygulamalar gibi itikadi anlamda heretik kabul edilebilecek düşünceler de bu ilkelerde dile getirilmiştir. Benzer şekilde Yahudilerin övüldüğü ve Tanrı'nın halkı olduğuna dair ifadelerin geçtiği yerlerin de dolaylı olarak Hıristiyanlığa eleştiri barındırdığı düşünülerek silinmesi karara bağlanmıştır. $\mathrm{Bu}$ ilkelerden sonra Domenico, yüzlerce eserin künyelerini vererek her bir kitapta hangi sayfa ve hangi satırda hangi kelimenin silineceğini kaydetmektedir. Bu eser, aynı zamanda Domenico'nun Yahudi dinî literatürüne vukufiyetini göstermektedir. Eserin bir diğer önemli yönü de o dönemdeki YahudiHıristiyan polemiğine dair canlı bir kayıt sunmasıdır. Zira bu eserde Kilise tarafından sakıncalı görülen ifadelerin bir arada yer aldığı görülmektedir. Nitekim law with the sheikh al-Islam and his teacher. The part also mentions the Ramadan and Sacrifice/Edha Feasts, the prayer for rain, the culling of dogs during the plague times, and the love of cats among the Turks. In addition, the four sects, differences in belief between Iranians and Turks, ablution, prayer, Friday prayers, the interior architecture of mosques, circumcision, jihad, charity, pilgrimage worship, belief in oneness, belief in prophethood are included in the fifth and the last chapter. The greatest surviving legacy of Domenico is the Sefer ha-Zikuk, which he prepared as a censorship manual. This work, which he prepared while dealing with censorship in Mantua in 1596, stands before us as one of the most impressive records in the history of censorship. In the introduction to this work, Domenico lists the basic principles that should be followed for censors. When this list is examined, the most important agenda item is to delete or change expressions that insult the Christian faith. Apart from this, ideas that can be considered heretical in the sense of creeds, such as reincarnation, jinn, evil spirits, and their related superstitious beliefs and practices, are also expressed in these principles. Similarly, it was decided to delete the places where the Jews were praised, and the statements that they were the people of God were thought to contain indirect criticism of Christianity. After these principles, Domenico tags hundreds of works and records which page and which word will be deleted in each book. This work also shows Domenico's knowledge of Jewish religious literature. Another important aspect of the work is that it presents a lively record of the JudeoChristian polemic of that period. Because the expressions considered objectionable by the Church seem to be 
Hıristiyan inanc1, İsa, Meryem, Kilise ve papazlarla ilgili hakaret ve eleştiri ifadelerinin silinmesi o dönemdeki gerilimi göstermesi açısından önemlidir. Sefer ha-Zikuk, birkaç asır boyunca kendisine atıf yapılan bir kitap olarak sansürcüler tarafından kullanılmıștır. Ancak her ne kadar Sefer ha-Zikuk'a atıf yapılmış olsa da, sansürcüler tarafindan içerisindeki talimatlara uyma noktasında gevşeklik gösterildiği tespit edilmiştir. İlginç bir şekilde Domenico'nun imzasını taşıyan ve günümüze ulaşan sansürlenmiş kitaplar incelendiğinde Domenico'nun da kendi belirlediği ilkelere pek fazla riayet etmediği görülmektedir. Araştırmacılar arasında genel kanaat, sansürcülerin Yahudi cemaatlerinden aldıkları para neticesinde birçok yeri görmezden geldikleri ve konuya hassasiyet göstermedikleri şeklindedir. Nitekim bu şekilde görev yaptığı tespit edilen bazı Yahudi dönmesi sansürcüler Kilise tarafindan görevlerinden uzaklaştırılmışlardır. included together in this work. The deletion of insults and criticisms about the Christian faith, Jesus, Mary, the Church, and priests is important in showing the tension in that period. Censors used Sefer ha-Zikuk as a reference book for several centuries. However, despite the reference to Sefer ha-Zikuk, it was determined that the censors showed laxity in obeying the instructions. Interestingly, when the censored books signed by Domenico that have survived to the present day are examined, Domenico himself seems not to follow the principles he has determined. The general opinion among the researchers is that the censors ignored many places and did not show sensitivity to the issue as a result of the money they received from the Jewish communities. The Church dismissed some Jewish convert censors who were detected to work in this way. 


\section{Giriş}

Katolik Kilisesi, Luther'in (ö. 1546) başlattığı Reform hareketine mukabelede bulunarak Karşı-Reform adı verilen bir dizi uygulamayı hayata geçirmiştir. $\mathrm{Bu}$ faaliyetlerden biri de yasaklı kitaplar listesinin (Index Librorum Prohibitorum) hazırlanması ve Hıristiyanlık açısından sakıncalı görüşler içeren kitapların sansüre tabi tutulmasıdır. ${ }^{1} 1559$ yılında yayınlanan yasaklı kitaplar listesinde Talmud'a da yer verilmiştir. ${ }^{2} 1564$ yılındaki listede ise Talmud ismi kullanılmamış ve Hıristiyanlığa yönelik saygısız ifadeler barındırmazsa Talmud'un hoş görülebileceği kaydedilmiştir. ${ }^{3}$ 1596'da Talmud tamamıyla yasaklanmıştır. ${ }^{4}$ Kilise, sonuncusu 194,8 yılında olmak üzere 4,2 defa Index listesi yayımlamıştır. 1966 yllında da bu gelenek lağvedilmiştir.

Kilise tarafından Talmud tamamen yasaklanırken, sansürden geçirilmesi şartıyla Yahudi dinî literatürüne ait diğer kitapların

Detaylı bilgi için bkz. George Haven Putnam, The Censorship of the Church of Rome (New York \& Londra: The Kneckerbocker Press, 1906-1907).

2 Tanah, Hıristiyanlar tarafından kabul edilmekle birlikte Yahudilerle Hıristiyanların Tanah'ı farklı şekilde yorumlamaları ve Yahudi geleneğinin Hıristiyanlıktan tamamen farklı zemin üzerinde devam etmesi Sözlü Tevrat olarak bilinen Talmud sebebiyledir. Hıristiyanlara göre Yahudilerin İsa'yı ve Hıristiyan inancını kabul etmelerinin önündeki en büyük engel Talmud'dur. Zira Talmud, üzerine bina edildiği şifahi gelenekle Yahudileri ayrı ve müstakil bir dinî gelenek olarak diri ve muhalif tutmaktadır. Bu sebeple de Kilise açısından bu engelin kaldırılması gerekmektedir. Daha önce birkaç defa toplanıp yakılan Talmudlar, 1553-1554 yıllarında da Kilise tarafından Yahudilerin evlerinden toplanarak yakılmıştır. Bkz. Jacob Rader Marcus \& Marc Saperstein, The Jews in Christian Europe: A Source Book 3151791 (Pittsburgh: Hebrew Union College Press, 2015), 221-224; Kenneth R. Stow, "The Burning of the Talmud in 1553, in the Light of Sixteenth Century Catholic Attitudes Toward the Talmud", Bibliotheque d'Humanisme et Renaissance 34:3 (1972): 435-459; Amnon Raz-Krakotzkin, The Censor, the Editor, and the Text: The Catholic Church and the Shaping of the Jewish Canon in the Sixteenth Century (Philadelphia: University of Pennsylvania Press, 2007), 32-64.

3 Federica Francesconi, "This passage can also be read differently ..." How Jews and Christians Censored Hebrew Texts in Early Modern Modena", Jewish History 26 (2012): 139. Kilise sadece Talmud'u değil, Talmud'dan üretilen bazı şerh, midraş ve konkordans türü eserleri de yasaklamıştır. Bu kitaplar için bkz. William Popper, The Censorship of Hebrew Books (New York: Knickerbocker Press, 1899), 35. Basllacak Talmud nüshaları için Talmud isminin yerine Şişa Sedarim, Gemara veya Limud kullanımları bu dönemde gündeme gelmiştir. Bkz. Moshe Carmilly-Weinberger, “External and Internal Censorship of Hebrew Books", Jewish Book Annual 28 (1970): 10; Popper, The Censorship of Hebrew Books, 59.

$4 \quad$ Amnon Raz-Krakotzkin, "The Censor as a Mediator: Printing, Censorship and the Shaping of Hebrew Literature", The Roman Inquisition, the Index and the Jews, ed. Stephan Wendehorst (Leiden: Brill, 2004), 37-40. 
bulundurulmasına izin verilmiştir. Bu çerçevede Kilise'nin oluşturduğu komisyonlar 16. asrın ikinci yarısından itibaren sakıncalı gördükleri İbranice kitapları sansürlemeye başlamıştır. ${ }^{5}$ Papa III. Julius, 29 Mayıs 1554 yılında yayınladığı bir fermanla (Cum sicut nuper) bütün İbranice kitapların incelenmek üzere Kilise otoritelerine teslim edilmesini duyurunca Yahudi cemaatler kendi içlerinde sansür mekanizmaları geliştirmişlerdir. 1 Haziran 1554'te Ferrara Yahudi cemaati hahamları, en az üç hahamdan onay almadan hiçbir kitabın basılmayacağına dair bir karar yayınlamışlardır. Kararda, onaysız basılan kitapları satın alanların para cezasına çarptırılacağ ifade edilmiştir. $^{6} 1$ Eylül 1554 tarihli bir belgede ise Roma Yahudi cemaati ileri gelenleri, İbranice kitapların sansürü (ha-zikuk me-hasfarim) işlerini takip etmeleri için beş kişilik bir haham heyeti kurmuşlardır. ${ }^{7}$ Benzer şekilde Mantua'da Yahudi hahamlardan Abraham ben David Provençal, cemaat içi sansürü takip etmek üzere görevlendirilmiştir. ${ }^{8}$ Yine $1603^{\prime}$ te Frankfurt'taki hahamlar meclisi, eski ya da yeni tüm Yahudi kitaplarının üç Yahudi mahkemesinden izin almadan bastırılamayacağına dair bir kararname yayınlamıştır. ${ }^{9}$

Kilise, İbranice kitapların sansür işlerini yürütmesi için genellikle Yahudi dönmelerini istihdam etmekteydi. Bilindiği üzere 16. asırda Papalığa bağlı bölgelerde Yahudilerden Hıristiyanlığ rastlanmaktadır. Bu kişilerin çoğu haham olan isimlerdir. O dönemlerde Yahudilerin Hıristiyanlığı seçme sebepleri farklıdır. Bazısı maddi imkânlar ve makam elde etmek amaciyla böyle bir tercihte bulunurken bazısı da samimi olarak İsa Mesih'in kurtarıcı olduğuna inandığını belirtmektedir. Yahudilere yapılan baskılar ve din değiştirenlere gösterilen kolaylıklar da din değiştirmelerde etkili olmuştur. İtalya'nın farklı şehirlerinde farklı komisyonlarda görev alan Yahudi dönmeler gerek matbaada basılmaya hazırlanan kitapları gerekse basılmış kitapları, buna ilaveten el yazmalarını

5 Bazı araştırmacılara göre, İbranice kitapların yasaklanması konusundaki kararlılık sadece Yahudilere yönelik değildir. Özellikle 15. ve 16. asırlarda Hıristiyan entelektüeller arasında İbranice ve Yahudi dinî literatürü konusunda uzmanlaşan Hıristiyanlar da (Hebraistler) bu vesileyle uyarılmak istenmiştir.

6 Louis Finkelstein, Jewish Self-Government in the Middle Ages (New York: The Jewish Publication Society Press, 1924), 301, 304.

$7 \quad$ Kenneth Stow, The Jews in Rome (Leiden: Brill, 1997), 2: 695.

$8 \quad$ Kilise'nin baskısı sonucunda Yahudilerin kendi cemaatleri içerisindeki sansür faaliyetleri ile ilgili detaylı bilgi için bkz. Isaiah Sonne, Expurgation of Hebrew Booksthe Work of Jewish Scholars: A Contribution to the History of the Censorship of Hebrew Books in Italy in the Sixteenth Century (New York: New York Public Library, 1943), 201241.

9 Marcus Horovitz, Die Frankfurter Rabbinerversammlung vom Jahre 1603 (Frankfurt: M. Slobotzky, 1897), 26-27; Finkelstein, Jewish Self-Government in the Middle Ages, 263. 
kontrolden geçirerek İsa ve Meryem başta olmak üzere Hıristiyan inancı, Kilise, Papalık ve papazlar hakkında küçük düşürücü ifadelere müdahale etmişlerdir. ${ }^{10}$ Müdahale birkaç şekilde karşımıza çıkmaktadır. Eğer kitap basılmışsa siyah bir mürekkeple sakıncalı kelime veya cümlelerin üzeri boyanmaktadır. Henüz basılmamış ise o kısımlar çıkarılarak basılmaktadır. Bazen ilgili pasajlar sayfada boş bırakılarak basılmıştır. Yazmalar söz konusu olduğunda da çıkarılması gereken yerler üzeri boyanarak kapatılmıştır. Sansüre tabi olan eserlerde bazen tek bir sansürcünün bazen 2, 3, 5 sansürcünün imzaları aynı anda yer almaktadır. Sansür masrafları kitap sahipleri tarafından karşılanmaktaydı. Bazı araştırmacılara göre, zaten sansürlenmiş ve üzerinde daha önceki sansürcülerin imzası olan kitaplar, Yahudileri haraca bağlamak için farklı tarihlerde tekrar tekrar sansüre tabi tutulmuştur. Bu çok imzalı kitapların metinlerinde sınırlı düzeyde sansür uygulanmış olması da bu iddiayı kuvvetlendirmektedir. ${ }^{11}$

$\mathrm{Bu}$ çalışmada Kudüs'te doğup Yahudi bir âlim olarak yetişen ve Osmanlı saray hekimliğinin ardından İtalya'ya giderek Hıristiyan olan Domenico Yeruşalmî isimli İbranice kitap sansürcüsü bir âlimin hayat hikâyesi aktarılacaktır. Bunu yaparken onun hayatının dönüm noktaları ve nihayetinde sansür faaliyetlerinin kitaplaştırıldığ Sefer ha-Zikuk adlı eseri incelenecektir.

10 Raz-Krakotzkin, The Censor, the Editor, and the Text, 85-89. Raz-Krakotzkin'e göre, sansürcüler Yahudilerin dinî literatürünün belirli sinırlar içerisinde muhafazasına katkı sağlamıştır. Bir diğer ifadeyle Yahudi dinî literatürünü yok etmek değil, Hıristiyan karşıtı olmayan ve kendisine müstakil bir alanı olan bir İbranice literatür oluşturmak istemişlerdir. O, Yahudiler, Hıristiyanlar ve Yahudi dönmesi sansürcülerin iş birliği içerisinde bir literatür oluşturduklarını, metnin de bunlar arasındaki tartışma ve müzakerelerin sonucu olduğunu öne sürmektedir. Sansür faaliyetinin de bu müzakerelerin temelini oluşturduğunu iddia etmektedir. Bkz. RazKrakotzkin, The Censor, the Editor, and the Text, 13-18, 22-26, 109-119; Amnon RazKrakotzkin, "Censorship, Editing, and the Reshaping of Jewish Identity: the Catholic Church and Hebrew Literature in the Sixteenth Century", Hebraica Veritas? Christian Hebraists and the Study of Judaism in Early Modern Europe, ed. Allison P. Coudert \& Jeffrey S. Shoulson (Philadelphia, University of Pennsylvania Press, 2004), 125-155. Raz-Krakotzkin'in bu iddiaları birçok araştırmacı tarafından eleştirilmiştir. Bkz. Piet van Boxel, "Hebrew Books and Censorship in Sixteenth-Century Italy", Jewish Books and their Readers, ed. Scott Mandelbrote \& Joanna Weinberg (Leiden: Brill, 2016), 90.

11 Adri K. Offenberg, "The Censorship of Hebrew Books in Sixteenth-Century Italy", Against the Law: Crime, Sharp Practice and the Control of Print, ed. Robin Myers v.dğr. (ed.) (New Castle: Oak Knoll Press, 2004), 26; Shifra Baruchson-Arbib \& Gila Prebor, "Sefer Ha-Ziquq (An Index of Forbidden Hebrew Books)-The Book's Use and its Influence on Hebrew Printing", La Bibliofilia 109:1 (2007): 18. 


\section{1) Domenico'nun İstanbul İzlenimleri}

$1555^{12}$ yılında Kudüs'te dünyaya gelen Domenico, aldığı eğitimden sonra hem haham hem dayan (kadı) hem de hekim olarak görev yapmıştır. ${ }^{13}$ Domenico'nun Yahudi iken adının Samuel Vivas olduğu 1593 tarihli vaftiz belgesinden anlaşılmaktadır. ${ }^{14}$ Aile ismi olan Vivas, onun İspanya Yahudilerinden olduğunu göstermektedir. ${ }^{15}$ Domenico, kendi otobiyografisinde Kudüs'te doğduğunu ve Filistin'in kuzeyindeki Celile bölgesinde eğitim aldığını belirtmektedir. $O$ dönemlerde Celile bölgesindeki en önemli eğitim merkezinin Safed olduğu bilinmektedir. Safed'de Yosef Karo (ö. 1575) gibi Yahudi hukukunda önde gelen isimler ve Yitshak Luria (ö. 1572) gibi Kabala üstatları bulunmaktaydı. Konuyla ilgili elimizde bir veri olmamakla birlikte aynı dönemde aynı bölgede bulunmaları sebebiyle Domenico'nun bu kişilerle yollarının kesişmiş olması ihtimal dâhilindedir. ${ }^{16}$

Domenico'nun hayatıyla ilgili bilgiler iki otobiyografi aracılığıyla günümüze ulaşmaktadır. Bunlardan ilki İbranice olup, 1616 yllında tamamlanan Yeni Ahit'in İbranice çevirisinin girişindedir. ${ }^{17}$ İkincisi de İtalyanca olup 1621 tarihli Domenico tarafından yazllan Aziz George'un Orta Doğu'daki kutsal makamlarını anlatan bir yazmanın içerisindedir. ${ }^{18}$ Domenico, İbranice biyografisinde Celile bölgesinde yetiştiğini, Yazılı ve Sözlü Tora'yı talim ettiğini, sivil hukuk, ticaret hukuku, Kabala ve diğer ilimlerle meşgul olduğunu, oradaki Yahudi cemaatlerinde uzun müddet hukuki otorite olarak görev yaptığını, daha sonra da İstanbul'a gittiğini anlatmaktadır. ${ }^{19}$ İtalyanca otobiyografide ise 1576 yılında sultanın kızıyla

12 Domenico'nun 1550 veya 1552 yılında doğduğuna dair bilgiler mevcut olsa da vaftiz belgesinden doğum tarihinin 1555 olduğu anlaşılmaktadır. Bkz. Pier Cesare Ioly Zorattini, "Domenico Gerosolimitano a Venezia", Sefarad 58 (1998): 110.

13 Gila Prebor, "mi-Yeruşalayim le-Venetsiya: Hayav şel Dominiko Yeruşalmî, Hiburav ve-Peiluto ke-Tsentsor", Pe'amim 111-112 (2007): 215.

14 Ioly Zorattini, "Domenico Gerosolimitano a Venezia”, 107-115.

15 David Corcos \& Getzel Kressel, "Bibas”, Encyclopedia Judaica (MI: Thomson Gale, 2007), 3: 571-572.

16 Prebor, "mi-Yeruşalayim le-Venetsiya", 219.

$17 \mathrm{Bu}$ çeviri, Biblioteca Apostolica Vaticana'nın Neofiti Koleksiyonu'nda yer almaktadır.

18 Gila Prebor, "Domenico Yerushalmi: His Life, Writings and Work as a Censor", Materia giudaica: Rivista dell'Associazione italiana per lo studio del giudaismo XV/XVI (2010/2011): 467-481.

19 Prebor, otobiyografinin tamamını makalesine ek olarak yayınlamıştır. Bkz. Prebor, "mi-Yeruşalayim le-Venetsiya", 238-239. Prebor, Yahudi kaynaklarında onun ismiyle anılan bir fetvaya veya Yahudilikle ilgili bir esere rastlanmadığını, bu sebeple Domenico'nun kendisinin otorite konumuyla ilgili söylediği ifadelerin kendinden menkul olduğunu öne sürmektedir. Bununla birlikte Yahudi dinî literatürüne olan 
Kahire üzerinden hac yolculuğuna gittiğinden ve Hz. Muhammed'in ${ }^{20}$ kabrini ziyaret etmelerinden bahsetmektedir. Bu ziyaret sirasında otuz yaşında olduğunu ve on altı yıldır sarayda hekimlik yaptığını belirtmektedir. ${ }^{21} \quad$ Metinde ayrıca kırk yaşındayken 1593 yılında Hıristiyanlığı benimsediğinden, bu yazıların yazıldığı esnada 21 yıllık Hıristiyan olduğundan, Roma'da ikamet ettiğinden ve İbranice öğrettiğinden bahsetmektedir. Elimizdeki son veriler ışı̆̆ında Domenico'nun verdiği tarihler ve yaşıyla ilgili rakamlar çelişkili olduğu için araştırmacılar bu tarihleri düzeltme ihtiyacı hissetmişlerdir. ${ }^{22}$

Domenico'nun İstanbul hayatına dair bilgiler sınırlı düzeydedir. O, 1611 yllında Roma'da bulunduğu sirada Relatione della Gran Citta di Costantinopli adlı eserini yazmıştır. ${ }^{23}$ Domenico, bu eserde kendi hayatını değil, ikamet ettiği dönemdeki İstanbul'u anlatmaktadır. Austin, eserdeki bilgilerden hareketle Domenico'nun 1578/9-1588/9 yılları arasında İstanbul'da olduğunu öne sürmektedir. ${ }^{24} \mathrm{Bu}$ da III. Murad'ın (hük. 1574-

hâkimiyeti Sefer ha-Zikuk adlı çalışmasında listelediği eserlerde görülmektedir. Bkz. Prebor, "Domenico Yerushalmi", 4,68. Domenico, biyografisinde Hz. Muhammed'den bahsederken "sahte peygamber Muhammed (falso profeta Maometto)" ifadesini kullanmaktadır.

${ }^{21} \quad$ Buradaki sultan kızı olarak zikredilen kişinin II. Selim'in kızlarından Hace Gevheri Mülük Sultan (Gevherhan Sultan) olduğu anlaşılmaktadır. Bkz. Michael Austin, Domenico's Istanbul (Londra: E.J.W. Gibb Memorial Trust, 2001), 142.

22 Prebor, "mi-Yeruşalayim le-Venetsiya", 217.

$23 \mathrm{Bu}$ eser Türkçeye tercüme edilmiştir. Domenico Hierosolimitano, Bir Yahudi Doktorun Harem, Saray ve İstanbul Hatıraları, çev. Esma Selçuk Demir (İstanbul: Yeditepe Yayınevi, 2017). Bu çeviri Michael Austin'in Domenico's Istanbul adlı İngilizce çevirisinin Türkçe tercümesidir. Maalesef İngilizce nüshada yer alan üç değerli ek Türkçe çeviride yer almamaktadır. Eseri intihal ederek kendi adlarıyla yayınlayanlarla ilgili bkz. Domenico Hierosolimitano, Bir Yahudi Doktorun Harem, Saray ve İstanbul Hattralar,, 23-31. Domenico, eseri ancak 1621'de Bologna'da bir matbaada bastırabilmiştir. Eserin kapağında kendisiyle birlikte Alfonso Cheirici'nin adı da yer almaktadır. Domenico'nun ölümünden sonra bu eser tekrar basılmış fakat Domenico'nun ismi silinmiş sadece Cheirici'nin ismi kalmıştır. Daha sonraki dönemde bu eser başka isimler tarafından da intihal edilerek basılmıştır. Leopold von Ranke bu eseri ilk keşfeden kişi olmuş fakat aidiyetini tespit edemeyip anonim bir eser olarak zikretmiştir. Eserin Domenico'ya ait olduğu ilk olarak 1919 yılında Emil Jacobs tarafindan tespit edilmiştir. Bkz. Prebor, “Domenico Yerushalmi”, 468.

24 Domenico Hierosolimitano, Bir Yahudi Doktorun Harem, Saray ve İstanbul Hatıralar,, 12. Domenico'nun İstanbul'a niçin ve ne zaman geldiği tam olarak bilinmemektedir. Her ne kadar Osmanlı sultanının Domenico'nun hekimlik şöhretini duyarak İstanbul'a getirttiğine dair ifadeler yer alsa da bunun abartı olduğu düşünülmektedir. Domenico'nun İstanbul izlenimlerini İtalyancadan İngilizceye tercüme eden Michael Austin'e göre, Domenico saraydaki Yahudi hekimler aracılığıyla İstanbul'a gelmiştir. O dönemlerde İstanbul'da sultanın sarayında Yahudi hekimlerin görev yapıyor olması ve İstanbul Yahudilerinin de Domenico gibi İspanya göçmeni olmaları bu 
1595) saltanat dönemine denk gelmektedir ki Domenico da ismen III. Murad'ın hekimi olduğundan bahsetmektedir.

Domenico'nun bu eseri beş bölümden oluşmaktadır. İlk bölümde şehrin kapıları, çeşmeler, camiler, saraylar, dükkânlar, yabancılar için kurulan hanlar, hastaneler, medreseler, vadiler, hamamlar ve meydanlar gibi yapilardan bahsetmektedir. Onun verdiği bilgiye göre o dönemde İstanbul'da Yahudilere ait otuz sekiz sinagog bulunmaktadır. ${ }^{25}$ İkinci bölümde şehirdeki idari, hukuki sistemden, vergilerden, medreseler, hocalar, şeyhler ve kadılardan bahsedilmektedir. Üçüncü bölümde sultanın yaşadığı saraydan ve diğer kullandığı saraylardan bahsedilerek kazasker, defterdar, yeniçeri ağası ve beylerbeyi gibi devlet erkânına değinilmektedir. Domenico, bu bölümde sultan için keçi sütüyle yoğrulmuş özel bir somun yapıldığını ve bundan herkese verilmediğini, fakat kendisinin padişahın üçüncü hassa doktoru olarak bu somundan alabildiğini belirtmektedir. ${ }^{26}$ Dördüncü bölümde sultanın günlük hayatı hakkında detaylı bilgiler verilmektedir. Beşinci bölümde ise genel anlamda İslam ile ilgili bilgiler verilmektedir. Dört mezhep, İranlılarla Türkler arasındaki inanç farklılıkları, abdest, namaz, cuma vaazları, sünnet, cihad, sadaka, hac ibadeti, tevhid inanışı ve peygamberlik inancı gibi hususlara bu bölümde yer verilmektedir.

Domenico, İstanbul'dan bahsettiği kitabında sultanın ekmeğinden yiyebildiğine dair bilgi verdiği tek cümle hariç kendisinden hiç bahsetmemektedir. Kitapta Yahudilerden de neredeyse hiç bahsedilmemektedir. Domenico, kendi Yahudi geçmişine dair bir ima da paylaşmamaktadır. Prebor, bu durumu Yahudi geçmişiyle bağları tamamen koparmak istemesine bağlamaktadır. ${ }^{27}$ Ancak kitap incelendiğinde Domenico, sadece kendisinden değil özel olarak hiçbir karakterden bahsetmemektedir. Zira kitap genel anlamda şehrin yapısına, milletin örfüne ve devletin yönetimine dair genel gözlemlere ayrılmıştır. Bu gözlemlerde de değerlendirmelerden kaçınan ve sadece gördüklerini tasviri bir dille anlatan bir üslup kullanılmaktadır. Bu sebeple kendisinden veya

ihtimali kuvvetlendirmektedir. Bkz. Domenico Hierosolimitano, Bir Yahudi Doktorun Harem, Saray ve İstanbul Hatıralar, 7-8.

25 Domenico Hierosolimitano, Bir Yahudi Doktorun Harem, Saray ve İstanbul Hatıralar, 55.

26 Domenico Hierosolimitano, Bir Yahudi Doktorun Harem, Saray ve İstanbul Hatıraları, 74.

27 Prebor, “Domenico Yerushalmi”, 471. 
İstanbul Yahudilerinden özel olarak bahsetmemesi anlaşlabilir bir durumdur. ${ }^{28}$

\section{2) Domenico'nun İtalya Macerası ve Hıristiyan Oluşu}

Domenico'nun İstanbul'u ne sebeple terk ettiği bilinmemektedir. İstanbul'dan ayrıldıktan sonra onunla ilgili ilk kayıt 1593 yllına ait Venedik'teki vaftiz belgesinde yer almaktadır. Bilindiği üzere Venedik ve İstanbul Yahudileri arasında güçlü bir iletişim mevcuttu. İstanbul ve Venedik'te basılan İbranice kitaplarla ilgili karşılıklı alışverişlerden de bu temasın güçlü olduğu görülebilmektedir. Aslen Venedikli olan ve II. Selim'in özel doktoru olan Şlomo Natan Aşkenazi'nin de Venedik'le yürütülen müzakerelerde Osmanlı tarafının temsilcilerinden birisi olarak yer aldığ kaynaklarda zikredilmektedir. Daha da ötesi Yahudi iken Hıristiyan olmaya zorlanan ve sureten Hıristiyan gibi yaşayan marrano veya converso diye bilinen Yahudi dönmelerinin en yoğun yaşadığı yerlerin başında Venedik gelmekteydi. Hatta bu dönmelerden bazıları İstanbul'a geldiklerinde Yahudiliklerini aşikâr etmişler ve Domenico tarafından sünnet edilmişlerdir. Bu çerçevede Domenico'nun da ilk tercihinin Venedik olması kuvvetle muhtemeldir. ${ }^{29}$

Domenico, 1 Temmuz 1593 yllinda Venedik'te ihtida ofisine başvurarak Hıristiyan olmak istediğini belirtmiştir. Vaftiz kaydında kendisinden "Kudüslü Samuel Vivas adında Levanten bir Yahudi (Samuel Vivas hebreo levantin da Gierusalem)" ifadesiyle bahsedilmektedir. 29 Temmuz'da Kilise, mühtedi adayının vaftiz babasını ve vaftiz seremonisi için uygun kılık kıyafetleri giydirecek kişileri belirlemiştir. Samuel Vivas, 6 Ağustos 1593 yllında Venedik'te Saint Giovanni e Paolo isimli Dominiken kilisesinde bir törenle vaftiz edilerek Hıristiyanlığı benimsemiştir. ${ }^{30}$ Vaftizden sonra kendisine Domenico ismi verilmiştir. Genel kanaat, Domenico'nun vaftiz olduğu günün Dominiken tarikatının kurucusu Domenico de Guzman'ın doğum günü olmasıdır. ${ }^{31}$ İtalyanca ve Latince Gerosolimitano, Irosolimitano ve Hierosolimitano gibi farklı şekillerde

28 Bkz. Domenico Hierosolimitano, Bir Yahudi Doktorun Harem, Saray ve İstanbul Hatiralarl, 14 .

29 Domenico Hierosolimitano, Bir Yahudi Doktorun Harem, Saray ve İstanbul Hatıralar,, 17.

30 Ioly Zorattini, "Domenico Gerosolimitano a Venezia", 107-108. Zorattini, vaftiz kaydını makalenin sonunda yayınlamıştır.

31 Prebor, "Domenico Yerushalmi", 471. Her ne kadar doğum tarihi dense de Aziz Dominik'in doğum tarihini 4-8 Ağustos arasında farklı günlere yerleştirenler mevcuttur. Ölümü ise ortak kanaatle 6 Ağustos 1221'dir. 
yazılan kelime "Kudüslü" anlamına gelmektedir. Aynı kelime İbranice "Yeruşalmî" şeklinde karşımıza çıkmaktadır. ${ }^{32}$

Otobiyografisinde Huristiyanlığa geçişini anlatan Domenico, bir arayışa girdiğini, hangi yolun doğru olduğuna kafa yorduğunu, arayışları neticesinde şu ana kadar yaşamını sürdürdüğü Yahudi inancının doğru yol olmadığını ve kurtuluşa ulaştırmayacağını anladığını belirtmektedir. Ona göre Tanrı'nın kurtuluş için belirlediği yol, İsa Mesih'in (Yeşua ha-Maşiah) yoludur. Domenico, gözlerinin aydınlandığını, üzerine manevi bir rahatlık geldiğini, kalbinin sıkıntılardan azade olduğunu, yeni bir kalp ve ruhla dolduğunu, Saul iken Pavlus olduğunu ve Hıristiyanlığın bu yüce inanç esaslarını karanlıkta yol alan halka (Yahudiler) öğreteceğini ifade etmektedir. ${ }^{33}$

Elimizdeki verilere göre Domenico, Hıristiyan olduğu sırada ekonomik sıkıntılar çekmekteydi. Nitekim vaftiz olduğu hafta kendisine mali destek verilmesi konusunda girişimlerde bulunması için şehrin Hıristiyan ileri gelenleri iki keşişi görevlendirmişlerdir. ${ }^{34}$ Domenico'nun Hıristiyan olduktan sonra da maddi durumunun iyi gitmediği anlaşılmaktadır. 1605 tarihinde Milan Kardinalı Federico Borromeo'ya gönderilen bir mektupta Domenico'nun evli, yaşlı ve çocuksuz olduğu ve kısıtlı imkânlarla yaşadığı zikredilmektedir. Yine 1607 tarihli bir başka belgede de Claudia Bottina isimli Karmelitan bir keşiş Kardinal Borromeo'ya Reggio Emilia'dan gönderdiği mektupta kitap satın alabilmesi için Domenico'ya borç para verdiğinden bahsetmektedir. ${ }^{35}$ Benzer şekilde İstanbul'u anlattığı 1611 tarihli eserinde de Domenico, kendisinden "ibret verici bir sabır hayatı yaşayan ve Kurtarıcımızın [İsa] aşkı için ziyadesiyle fakirlik çeken" ifadelerini kullanmaktadır. ${ }^{36}$

Domenico, vaftiz olduktan sonra Kilise tarafından İbranice kitapların sansür komisyonunda istihdam edilmiştir. Elimize ulaşan kayıtlara göre, Kilise'nin en etkili sansürcülerinden birisidir. Domenico'nun sansüründen geçmiş ve imzasının yer aldığı yüzlerce eser günümüze gelmiştir. Kendisi de Sefer ha-Zikuk adlı eserinin girişinde 20.00o'in üzerinde eseri sansürlediğini belirtmektedir. Hatta o, İtalya'nın hangi şehrinde kaç eseri sansürlediğine dair bir liste de paylaşmaktadır. Bu listede en yüksek rakam 13.991 ile Mantua'ya aittir. Listede Milan, Roma, Viadana, Ostiglia, Revere, Verola, La Volta ve Castigliano gibi farklı yerlerin isimleri bulunmaktadır. Listede

\footnotetext{
32 İlgili belgede Domenico'nun 11 Şubat 1594'te Venedik'ten ayrıldığı belirtilmektedir.

33 MS. Neofiti 32, Ib. Bkz. Prebor, "Domenico Yerushalmi”, 472.

34 Ioly Zorattini, "Domenico Gerosolimitano a Venezia”, 108.

35 Prebor, "Domenico Yerushalmi: His Life, Writings and Work as a Censor", 473.

36 Domenico Hierosolimitano, Bir Yahudi Doktorun Harem, Saray ve İstanbul Hatıralar, 74 .
} 
ayrıca el yazmalarını da elden geçirdiği görülmektedir. ${ }^{37} \mathrm{Bu}$ şehirler arasında Venedik yer almamaktadır. Vaftiz olmasını takip eden günlerde Venedik'te Eusebio Renati ile İbranice kitapların basım öncesi ve sonrası incelenmesinde birlikte çalıştıkları bilinmektedir. Fakat Domenico'nun bu sırada sansürcü olarak istihdam edildiğine dair bir veri yoktur. ${ }^{8}$ Onun bu görevi resmi olarak ilk yürütmeye başladığı yer Mantua'dır. Domenico'nun sansürlediği kitaplar arasında tespit edilebilen en erken tarih 1595 veya 1596'dır. ${ }^{39}$ Domenico'nun sansürcü olarak imzasını attığı son tarih, 1621'dir.

Domenico'nun 1595-1621 yılları arasındaki sansürcülük kariyerinde en fazla imzası bulunan yıl Mantua'da bulunduğu 1597 yılıdır. Domenico, Mantua'da bulunduğu iki yıllık zaman diliminde (1595-1597) şehrin episkoposu Franscesco Gonzaga tarafından Ağustos 1595 yılında AlessandScipione ve Lorenzo Granguelloro ile birlikte sansür komisyonuna atanmıştır. ${ }^{\circ 0} \mathrm{Bu}$ iki isim de aslen Yahudi olup Domenico gibi sonradan Hıristiyan olmuşlardır. Mantua Yahudilerinden, ellerindeki bütün İbranice kitapları engizisyon idaresinin sansür komisyonuna getirmeleri istenmiştir. Kitapları getirmeyenler veya gizleyenler kitaplarının haczedilmesi, para veya hapis cezası verilmesi gibi farklı cezalarla tehdit edilmişlerdir. ${ }^{41}$ Sansür komisyonunun denetiminden geçirilen eserler sahiplerine iade edilmiştir. ${ }^{42}$ Kisa bir süre sonra getirilen kitapların sansürlenmesi ve iade edilmesiyle baş edilemeyeceği görülünce episkopos, Yahudi ailelerin ileri gelenlerine ve sinagog yetkililerine gerek İbranice gerekse diğer dillerde ellerinde bulunan kitapların listesini yapıp bu listeyi sansür komisyonuna teslim etmeleri çağrısında bulunmuştur. Aynı yılın ekim ayında Kilise ileri gelenleri, Yahudi cemaatini harcadıkları mesai ve emek sebebiyle sansürcülere 4,00 scudi ücret ödemekle yükümlü tutmuştur. ${ }^{43}$ Eldeki verilere göre kitap listeleri, ancak 1596 Şubat ayında

Shlomo Simonsohn, "Sfarim ve-Sifriyot şel Yehudey Mantuva, 1595", Kiryat Sefer 37:1 (1961): 105; Prebor, "Domenico Yerushalmi", 475; Nathan Porges, "Der hebräische Index expurgatorius", Festschrift zum siebzigsten Geburtstage A. Berliner's, ed. A. Freimann \& M. Hildesheimer (Frankfurt: J. Kaufmann, 1903), 285; Prebor, "miYeruşalayim le-Venetsiya”, 228.

38 Ioly Zorattini, "Domenico Gerosolimitano a Venezia”, 110.

39 Prebor, "Domenico Yerushalmi", 475.

40 Simonsohn, "Sfarim ve-Sifriyot şel Yehudey Mantuva, 1595", 105; Prebor, "miYeruşalayim le-Venetsiya", 231.

$41 \quad$ Nathan Porges, “Censorship of Hebrew Books”, Jewish Encyclopedia (New York: Funk and Wagnalls, 1903), 3: 644.

42 Baruchson-Arbib \& Prebor, "Sefer Ha-Ziquq (An Index of Forbidden Hebrew Books)", 7-8.

43 Simonsohn, "Sfarim ve-Sifriyot şel Yehudey Mantuva, 1595", 105; Offenberg, "The Censorship of Hebrew Books in Sixteenth-Century Italy", 24-25; Prebor, "miYeruşalayim le-Venetsiya", 232; Baruchson-Arbib \& Prebor, "Sefer Ha-Ziquq (An 
heyete sonradan katılan Claudio Fina isimli sansürcüye teslim edilebilmiştir. Bu kitapların kahir ekseriyeti 1597 yılı içerisinde sansürden geçirilmiştir. Domenico da muhtemelen ihtiyaca binaen Sefer ha-Zikuk adlı eserinin ilk versiyonunu Ağustos 1596 yılında hazırlamıştır. ${ }^{44}$ Benzer bir sansür kampanyası 1605 yılında yapılmıştır ve orada da Domenico Yeruşalmî en kritik isim olarak karşımıza çıkmaktadır. O zamanki listeden günümüze ulaşan 430 kitaptan neredeyse tamamında Domenico'nun imzası yer almaktadır. ${ }^{45}$

Domenico'nun Mantua'dan sonra yine İbrani kitaplarının sansür işlemlerini yapmak üzere 1598 yılında Ferrara şehrine geçtiği düşünülmektedir. Muhtemelen Domenico orada sadece bir yıl kalmıştır. ${ }^{46}$ Domenico'nun 1599-1605 yılları arasında da Mantua'da olduğu düşünülmektedir. Bu dönemde Giovanni Domenico Carretto isimli bir başka sansürcünün de heyette görev aldığı görülmektedir. ${ }^{47} 1605$ yılında daha sonra Pesaro şehrinin episkoposluğunu yapan Bartolomeo Giorgi (ö. 1612), Mantua'ya ziyarete gelmiş ve burada Domenico'nun faaliyetlerine şahit olarak ondan istifade etmek istemiştir. Giorgi, bunun için Milan Kardinalı Federico Borromeo'ya bir mektup göndererek Domenico'nun Milan'da istihdam edilmesini talep etmiştir. Mantua episkoposu Vincenzo Gonzaga ile görüşmelerden sonra Domenico, 1605 yılında Milan'daki Ambrosiana Kütüphanesi'ne gitmiş̧ir. Domenico, burada İbranice öğreticiliği yapmış, Yahudilere yönelik münazara konuları hakkında

Index of Forbidden Hebrew Books)", 8. Kilise açısından bakıldığında, kitapların ellerinden alınmasıyla kitapların sansüre tabi tutulması arasındaki bir tercihte, Yahudiler sansürle ödüllendirilmektedir. Bu durum Index listelerinde olan ve bulundurulması tamamıyla yasak olan kitaplar için geçerli değildir. Nitekim Talmud tamamen yasaklanmıştır. Bu durumda İbranice kitapların tamamen yasaklanması yerine içeriklerinde İsa, Meryem ve Kilise hakkında sakıncalı ifadeler çıkartılarak Yahudiler tarafından kullanılmasına izin verilmektedir. Böyle yaparak Kilise, aslında bir ara formülle Yahudilere ihsanda bulunduğunu düşünmektedir. Verilen bu sansür hizmeti karşısında da Yahudilerin ödeme yapması şart koşulmuştur. Bu çerçevede sansür, Kilise tarafından Yahudi cemaatine kitapları ellerinde tutabilmeleri için sunulan zorunlu bir hizmet olarak görülmektedir. Kasabalarda veya köylerde yaşayıp kitaplarını getirmeyenler için sansürcüler o yerlere gittiklerinde kitap sahipleri tarafından sadece yol masraflarının karşılanmasını kabul etmişlerdir. Bkz. Simonsohn, "Sfarim ve-Sifriyot şel Yehudey Mantuva, 1595”, 104-105; Prebor, “Sefer ha-Zikuk şel Dominiko Yeruşalmî”, 22.

44 Baruchson-Arbib \& Prebor, "Sefer Ha-Ziquq (An Index of Forbidden Hebrew Books)", 4; Prebor, "mi-Yeruşalayim le-Venetsiya", 232; Prebor, "Domenico Yerushalmi", 477-478.

45 Prebor, "Domenico Yerushalmi", 478; Prebor, "mi-Yeruşalayim le-Venetsiya: 232.

46 Prebor, "mi-Yeruşalayim le-Venetsiya", 232; Popper, The Censorship of Hebrew Books, 141; Prebor, "Domenico Yerushalmi", 479.

47 Prebor, “Domenico Yerushalmi”, 479; Prebor, "mi-Yeruşalayim le-Venetsiya”, 232. 
bilgiler vermiş ve İbranice yazmaların/eserlerin sansürlenmesiyle ilgilenmiştir. ${ }^{48}$ Milan kardinali 1607 yılında Domenico'yu yazma toplaması amacıyla Corfu şehrine göndermiştir. Domenico'nun aynı sene Milan'a dönüp görevine devam ettiği anlaşılmaktadır. ${ }^{49}$ Domenico, 1610 yılına kadar Milan'da Ambrosiana Kütüphanesi'nde görev yapmıştır. 1606-1611 yılları arasında Domenico'nun imzasıyla sansürden geçirilmiş bir kitap günümüze ulaşmamıştır.

Domenico, 1611 yılında İstanbul'la ilgili gözlemlerini kaleme aldığı kitabını yazmıştır. Bu kitabın içerisinde geçen "Şu anda Roma'da Tanrı'nın lütfuyla bir Hıristiyan olarak yaşayan Kudüslü Domenico" ifadesinden ötürü 1611 yılında Roma'ya intikal ettiği düşünülmektedir. Domenico'nun Roma'daki görev yeri, mühtedilerin koleji olarak bilinen Collegio dei Neofiti'dir. Neofiti kelime anlamı olarak "yeni imanlı" demektir. Bununla da yeni Hıristiyan olmuş kişiler kastedilmektedir. Bu kolej Yahudilikten Hıristiyanlığa geçmiş kişilerin din eğitimi almaları ve daha sonra Yahudi cemaatlerine gönderilerek misyonerlik faaliyetlerinde kullanılmaları için 1577 yılında Papa 13. Gregory tarafından kurulmuştur..$^{50}$ Domenico burada hem hocalık yapmış hem eser üretmiş hem de sansürcü olarak çalışmıştır. 1616-1617 yıllarında Domenico, Roma'da Yeni Ahit'i ve bazı apokrif kitapları İbraniceye tercüme etmiştir. Eldeki verilere göre Domenico, hayatını kaybettiği 1622 yılına kadar Roma'da yaşamıştır. 22 Aralık 1622 tarihinde Milan Kardinali Borromeo'nun Roma'daki temsilcisi Papirio Bartoli, kardinale gönderdiği bilgi notunda "Domenico Gerosolimitano vefat etti" ifadelerini kullanmış ve onun incelediği kitapları titizlikle gözden geçirdiğini belirtmiştir. ${ }^{51}$

Domenico, sansürlediği kitaplarda ve otobiyografisinde ismini İbranice Domenico Yeruşalmî, Latince Domenicus Hierosomilitanus veya Dominicum Hyerosolimitanum, İtalyanca yazdığı eserlerde ise Domenico Irosolomitano veya Dominico Irosolomitano sseklinde yazmaktadır. ${ }^{52}$ Domenico, 1595-1605 yılları arasında sansürlediği kitaplara Latin karakterlerle imzasını atmaktadır. 1612 ve sonrasındakilerde ise hem

48 Ignazio Guidi, “Domenico Gerosolimitano”, Festschrift zum siebzigsten Geburtstage A. Berliner's, ed. A. Freimann \& M. Hildesheimer (Frankfurt, 1903), 176-177; Prebor, “Domenico Yerushalmi”, 477, 480; Sonne, Expurgation of Hebrew Books, 206; Prebor, "mi-Yeruşalayim le-Venetsiya", 235-236.

49 Prebor, “Domenico Yerushalmi”, 479-480.

50 Tevrat'ın Aramice çevirilerinden Targum Neofiti, bu kolejin kütüphanesinde yer aldığı için bu isimle anılmaktadır. Kolej, 1886 yılında kapanmıştır.

51 Lucia Rostagno, "Note su Domenico Gerosolimitano. A proposito del recente saggio di M. Austin. Parte I", Rivista degli Studi Orientali 76 (2002): 237.

52 Prebor, "Domenico Yerushalmi", 471, 476-477; Popper, The Censorship of Hebrew Books, 61. 
İbranice hem de Latin karakterleriyle imzalar bulunmaktadır. Sadece İbranice imza atılan eserlerde imzanın yanında "Bu kitabı gerektiği şekilde inceledim ve sansürden geçirdim, ben Dominico Yeruşalmî (hakarti ve zikakti ha-sefer ha-ze ka-rauy ani dominiko yeruşalmi)" şeklinde bir not yer almaktadır. ${ }^{53}$

Domenico'nun Yahudi bir âlim olarak Hıristiyanlı̆̆ benimsemesi ve eski dindaşlarını Hıristiyan yapmaya çalışması bağlamında Kilise'nin onu başka işler için de kullanmak istediği anlaşılmaktadır. Bunlardan biri de İspanya'da zorla Hıristiyan yapılan ve sonrasında İtalya'ya göç eden marranolardır. Domenico'nun 1594'ün Aralık ayında Venedik'te bulunduğu anlaşılmaktadır. Bu sırada Portekiz asıllı bir keşiş, İtalya'ya geldikten sonra gizli veya açıktan Yahudiliğe dönen marranoların tespiti için Roma engizisyon makamından Domenico Yeruşalmî'nin istihdam edilmesini talep etmiştir. Talep yazısında İstanbullu bir haham olan Domenico'nun Papalık tarafından Roma'ya bir bahane üretilerek çağrılması teklif edilmektedir. Zira onun davet edilmesi Venedik'te Yahudiliğe dönen marranolar arasında şüphe yaratmayacaktır. Daha önce haham olan Domenico'nun, Roma'daki engizisyon makamlarına Venedik'te Yahudiliğe dönen ve çifte kimlikle yaşayan marranolar hakkında çok kıymetli istihbarat sunabileceği düşünülmüştür. Zira Domenico, bu dönmeleri şahsen tanımaktadır. Bu belgeden hareketle eski bir haham olan Domenico'nun Yahudi cemaatinin içerisinde casus olarak istihdam edilmek istendiği anlaşılmaktadır. Bir başka belge ise İstanbul'da ikamet ettiği dönemlerde İspanya ve İtalya'dan gelen zorla Hıristiyan yapılmış Yahudilerin tekrar Yahudiliğe döndürülmesi, onların sünnet ettirilmesi gibi hususlarda Domenico'nun aktif olarak görev aldığına dairdir. Şimdi ise Domenico, tam tersi bir görev için istihdam edilmek istenmektedir. Bir başka Portekiz asıllı keşişe ait bu belgede, Domenico'nun İstanbul'da hekim olduğu sırada Portekiz asıllı dönmelerin tekrar Yahudiliğe geçmelerine aracı olduğu dile getirilerek bunlara Lizbon Yahudi cemaatinden olan ve Venedik'te yaşayan Garcia, Manoel ve Alvaro Pimentel isimli üç kardeş örnek gösterilmektedir. Belgeye göre Alvaro Pimentel, dört yll kadar önce tekrar Yahudiliğe geçebilmek için İstanbul'a göç etmiş, orada sultanın doktoru Domenico ile buluşmuş, sünnet olmuş ve Venedik'e dönerek gettonun dişında yine Hıristiyan gibi yaşamaya devam etmiştir. Domenico'nun Venedik'e gelerek Hiristiyan olmasiyla birlikte Alvaro'nun huzurunun bozulduğu ve Kilise otoritelerine ihbar etmemesi konusunda

53 Prebor, "Domenico Yerushalmi", 477; Sonne, Expurgation of Hebrew Books, 204; Popper, The Censorship of Hebrew Books, 61. 
Domenico'yu tehdit ettiği ifade edilmektedir. ${ }^{54}$ İstanbul-Venedik Yahudi cemaatlerinin irtibatı düşünüldüğünde Domenico'nun Hıristiyan olması, Venedik'teki marranoları ciddi anlamda endişeye sevk etmiş olmalıdır. Onun bu görevi yürütüp yürütmediğine dair kesin bir bilgi olmamakla birlikte Yahudileri Hıristiyanlaştırmak için gösterdiği çaba dikkate alınırsa ihtimal dâhilinde olduğu söylenebilir.

Domenico'nun Hiristiyan olduktan sonra yazdığı ilk eser, Sefer haZikuk'tur. Kitabın mukaddimesinde karanlıkta yürüyen Yahudi halkının gözlerini hakikate açmak ve Hıristiyanlığın hakikatlerini ortaya koymak için bu eseri hazırladığını ifade etmektedir. İlk versiyonu 1596 yılında hazırlanan eser, Domenico'nun yaşamı süresince önemli bir etki bırakmış ve diğer sansürcüler tarafından da el kitabı olarak kullanılmıştır. Domenico'nun Ma'yan Ganim ismini taşıyan diğer eseri, Hıristiyanlık ve Yahudilik arasındaki münazara konularını ele almaktadır. Domenico, eseri tanıtırken hacimce geniş, içerik olarak da nitelikli bir eser olduğunu, bu eserde Yahudilerin Hıristiyan inancına dair bütün yanlışlarını gözler önüne serdiğini, Hıristiyanlığın inanç esaslarını izah ettiğini nakletmektedir. ${ }^{55} \mathrm{Bu}$ veriler ışığında ve Domenico'nun kendi ifadelerinden hareketle onun samimi bir şekilde Hıristiyanlığı benimsediği sonucu çıkarılmaktadır.

Domenico, Sefer ha-Zikuk ve Ma'yan Ganim adlı eserlerine ilaveten Yeni Ahit'i İbraniceye tercüme etmiştir. ${ }^{56}$ Domenico'nun bu faaliyetleriyle eski dindaşlarını Hıristiyanlığa çekmeye ve onlara bu konuda yardımcı olmaya çalıştığı anlaşılmaktadır. Domenico, ayrıca buradaki otobiyografisinde Baba, Oğul ve Kutsal Ruh'un lütfuyla Yeni Ahit'i (ha-Edut ha-Hadaşa) Aramice/Süryanice, Yunanca, Latince ve Arapça versiyonlarından kutsal dil İbraniceye tercüme ettiğini belirtmektedir (Anohî ha-dal ve-ha-tsa îr zikenî ha-El Av ve-Ben ve-Ruah Kadoş le-ha'atik et ha-Edut ha-Hadaşa mi-laşon Aşurî ve-Yavanî ve-Romî ve-Hagrî el-laşon ha-kadoş laşon iurî). ${ }^{57}$ Neofiti 34

54 Ioly Zorattini, “Domenico Gerosolimitano a Venezia”, 112-113.

55 Prebor, "mi-Yeruşalayim le-Venetsiya:", 225. Bartolomeo Giorgi, Milan kardinaline yazdığı 1605 tarihli mektupta Domenico'nun Yahudilerle Hıristiyanlar arasındaki münazaralar hakkında bir kitap yazdığını fakat bastırmakta sıkıntı çektiğini aktarmaktadır. Domenico, 1621 tarihli bir yazısında da Yahudilere reddiye olarak yazdığı eserin yakın zamanda Paris'te basıldığından bahsetmektedir. Domenico'nun sözünü ettiği eserin Ma'yan Ganim olduğu düşünülmektedir. Fakat bu eser, yazma veya matbu halde günümüze ulaşmamıştır. Bkz. Guidi, “Domenico Gerosolimitano”, 177; Austin, Domenico's Istanbul, 14,2.

56 Bu çeviri hakkında detaylı bilgi için bkz. Dina Blokland, The Gospel according to Matthew in the Translation of Domenico of Jerusalem, a Jew who Became a Christian (Doktora Tezi, Kudüs: Kudüs İbrani Üniversitesi, 2019).

57 MS. Neofiti 32, Va. 1616-1617 yıllarıyla tarihlendirilen ve Domenico'nun kendi el yazısıyla kaleme aldığı bu yazmalardan Neofiti 32 numaralı yazmanın 1a-229a varakları arasında dört İncil'in İbranice tercümesi yer almaktadır. 1a-63a arasında 
numaralı yazmada ise Yahudi apokrif kitaplarının İbranice tercümesi yer almaktadır. ${ }^{58}$ Domenico'nun Neofiti yazmalarından 36, 40 ve 4,1 numaralı yazmalarda yer alan toplam 73 adet vaazı da Prebor tarafindan keşfedilmiştir. Bu vaazlar genellikle Eyüp, Mezmurlar ve Vaiz kitaplarındandır ve İbrani harfleriyle İtalyanca olarak kaleme alınmıştır. ${ }^{59}$

\section{3) Domenico'nun Hazırladığı Sansür El Kitabı: Sefer ha- Zikuk}

Domenico Yeruşalmî'den günümüze ulaşan en önemli miras Sefer haZikuk adındaki sansür kitabıdır. ${ }^{60}$ Zikuk kelimesi, "arındırma, temizleme, saflaştırma” gibi anlamlara gelip Latince “expurgatio" kelimesinin karşılığı olarak kullanılmaktadır. Sefer ha-Zikuk'ta toplam 472 eserin listesi ve bu eserlerde silinmesi ve değiştirilmesi gereken kelime, cümle ve pasajlar yer almaktadır. $\mathrm{Bu}$ eserlerden sadece dördü el yazması olup diğerlerinin tamamı matbaa baskısı kitaplardır. ${ }^{61}$ Talmud, bulundurması her hâlükarda yasak olan kitaplardan olduğu için Sefer ha-Zikuk'ta yer almamaktadır. Domenico'nun, Sefer ha-Zikuk adlı kitabının girişinde sunduğu temel sansür ilkeleri şu şekildedir: ${ }^{62}$

Besorat Mattay başlığıyla Matta İncili, 64a-105b arasında Besorat Markus başlı̆̆ıyla Markos İncili, 106a-178b arasında Besorat Luka adıyla Luka İncili ve 179a-229a varakları arasında da Keruzat Yohanan başlığıyla Yuhanna İncili'nin İbranice tercümesi yer almaktadır. Neofiti 33 numaralı yazmada ise Elçilerin İşleri'nden başlayarak Yeni Ahit'in diğer kitapları yer almaktadır. Bkz. Biblioteca Apostolica Vaticana, "Neofiti.33", erişim: 3.11.2021,

http://www.mss.vatlib.it/guii/console? service=shortDetail\&cid=255249.

Bunlar arasında Baruh Kitabı, Yeremya'nın Mektubu, Süleyman'ın Hikmeti, Ben Sira, Menaşşe'nin Duası, Suzanna, Bel ve Ejderha, Yudit, Tobit ve Aristeas'ın Mektubu gibi eserler yer almaktadır. Bkz. Biblioteca Apostolica Vaticana, "Neofiti.34", erişim: 3.11.2021, http://www.mss.vatlib.it/guii/console? service=shortDetail\&cid=195872. Biblioteca Apostolica Vaticana, "Neofiti.36", erişim: 3.11.2021, http://www.mss.vatlib.it/guii/console?service=shortDetail\&cid=19594.6. Ayrıca bkz. Gustavo Sacerdote, I codici ebraici della Pia Casa dei Neofiti in Roma (Roma: Tipografia della R. Accademia dei Lincei, 1893), 178-181; Prebor, "mi-Yeruşalayim leVenetsiya", 226-227; Prebor, "Domenico Yerushalmi”, 474-475.

6o Gila Prebor, "Sefer ha-Zikuk şel Dominiko Yeruşalmî”, Italia 18 (2008): 7-302.

61 Baruchson-Arbib \& Prebor, "Sefer Ha-Ziquq (An Index of Forbidden Hebrew Books)", 5; Gila Prebor, "Sefer ha-Zikuk ke-Makor Bibliyografî", Aley Sefer 23 (2013): 64-65.

62 İbranice metin için bkz. Prebor, "Sefer ha-Zikuk şel Dominiko Yeruşalmî", 53-54; Amnon Raz-Krakotzkin, ha-Tsentsor, ha-Oreh ve-ha-Tekst: ha-Tsentsura ha-Katolit veha-Defus ha-İurîbe-Mea ha-Şeş Esra (Kudüs: Magnes Press, 2005), 148-149; Porges, "Der hebräische Index expurgatorius", 286-288. İngilizce çeviri için bkz. Raz-Krakotzkin, The Censor, the Editor, and the Text, 121-123; Popper, The Censorship of Hebrew Books, 82- 
1. Maksadi tam bir şekilde anlaşılmayan ve eski putperestlik dönemine işaret ettiği açıç̧a belli olmayan bütün avoda zara (putperestlik) tabirlerinin yerine "yıldızlara ve burçlara tapanlar" anlamina gelen akum ${ }^{63}$ kelimesi yazllacaktır. Eğer avoda zara tabirinin, efendimizin [İsa] gelişinden önceki döneme işaret ettiği anlaşllıyorsa o zaman sorun yoktur.

2. Her türlü put isminin yanına da benzer şekilde "yıldızlara ve burçlara tapanların (şel akum)" ifadesi yazllacaktır.

3. Goy, goyim, nohri, nohrit kelimesi geçtiği yerde goya yönelik herhangi bir eleştiri, hakaret ve olumsuzlama varsa kelime silinecek ve yerine akum yazllacaktır. Eğer pasaj Şabat, yasak yiyecekler, goyun dokunduğu şarap gibi Yahudilerin hukuki konularindan birinden bahsediyorsa o zaman sorun yoktur.

4. Fakat bunlarda hiçbir şekilde avoda zara'dan bahsedilmeyecektir. "Nohrilerin düşünceleri avoda zara'dır" ve "goy, avoda zara için şarap döker" gibi ifadelerin bulunduğu yerler tamamen silinecektir.

5. Bütün min (heretik) ve minim (heretikler) kelimeleri tamamen silinecektir.

6. Meşumad kelimesi eğer hakaret içermiyorsa silinip ${ }^{64}$ yerine akum kelimesi yazlacaktır. Eğer hakaret içeriyorsa tamamen silinecektir.

7. Uma (millet) ve umot (milletler) geçen bütün kelimelerin yanina akum kelimesi yazlacaktir.

8. Eğer umot kelimesi genel anlamda bugün dünyanın milletleri şeklinde ya da özel olarak bu dönemdeki bizim milletimiz (Hıristiyanlar) olarak anlaşılıyorsa ilgili kısmın tamam silinecektir. Zira akum kelimesini eklemek suretiyle düzeltmeye çalışmak bu kısmı daha sorunlu hale getirir.

9. Bize hakaret iması taşıyan ve günümüz için söylendiği anlaşılan Yahudi milletine yönelik bütün övgüler silinecektir.

83. Listenin metni ortak olsa da edisyonunu yapanlar metni farklı yerlerinden bölerek listelemişlerdir. Biz burada Prebor'un bölümlemesini esas aldık.

63 Ovdey kohavim u-mazalot (yıldızlara ve burçlara tapanlar) kelimelerinin kısaltılmış hali. Yahudilerin akum kelimesini de Hıristiyanlara yönelik tahkir amaçlı olarak ovdey Kristos u-Maria (Mesih ve Meryem'e tapanlar) şeklinde kullandıklarına dair iddialar bulunmaktadır. Nitekim Wagenseil, eserinde akum kelimesinin ovdey kohavim u-mazalot şeklinde açıklandığını, fakat Yahudilerin bu kelimeyi ovdey Kristos u-Maria şeklinde okuduklarını iddia etmektedir. Bkz. Johann Christoph Wagenseil, Tela ignea Satanae (Altdorf, 1681), 120-121. Yahudi müellifler, Avrupa'da zaman zaman bu ithama maruz kalmışlardır.

64 İbranice metinde "lo yimahek (silinmeyecek)" şeklinde yer alsa da Porges'in düzeltmesinde olduğu gibi "silinecek" şeklinde olması daha doğrudur. Bkz. Porges, "Der hebräische Index expurgatorius", 287. 
10. Sünnet derisiyle ilgili küçük düşürücü her ifade erken dönemlere atfedilmek suretiyle özelleştirilecektir. Mesela "sünnet derisi iğrençtir" (meusa hi arela) ${ }^{65}$ cümlesinin "sünnet derisi iğrençti" (meusa hayta arela) şeklinde olmasi gerekmektedir. ${ }^{66}$

11. Tanah'ta Yahudilerin inancıyla bizim inancımız arasinda polemik ve farklılık konusu olan her yerde, eğer bizim anlayışımızı çürütmeye yönelik açı bir ifade ya da Yahudilerin görüşünü destekleyecek bir delil varsa, Hıristiyan âlimlerin ve hahamlarının isimleri açıça zikredilmese bile ilgili kısmın tamamı silinmelidir. Fakat konu kendi görüşleri istikametinde şerh edilmişse ve görüşümüzü çürütmeye yönelik herhangi bir şey yoksa bu durumda sorun yoktur.

12. Hukuki kurallarımızdan herhangi birine, öğretilerimize, törelerimizden birine ya da bir uygulamamiza veya bir kral, prens veya milletimizin kutsal papazlarindan birine yönelik küçük düşürücü ifadelerin olduğu bütün yerler tamamiyla silinecektir.

13. Reenkarnasyon, bütün ruhların dünyanın yaratıldığı altı günlük süreçte yaratıldığı, Tanrı'nın ağladığı, kötü ruhların cinler ve mazikler (zarar veren görünmezler) olduğu, insanların bedenlerine giren kötü ruhlarin ölen şerli insanların kötü ruhlarl olduğu gibi ve benzeri büyük küfür ve büyük yanlş̧lılar içeren her yer tamamıla silinecektir.

14. Edom, Roma ve İtalya'dan hakaret ifadeleriyle bahseden her yer silinecektir.

15. Tanrı'nın, Yahudilerin yok olmasına üzüldüğünden bahseden her yer tamamiyla silinecektir.

16. Portekiz ve İspanya'da ölenler gibi, insanların dinleri için öldüklerinden bahseden yerlerde, bu kişilerin şehit (kiduş ha-şem) olduklarından bahsediliyorsa ya da bu ölen kişiler için tsadikim (salihler) ve kadoşim (mübarekler) gibi sifatlar kullanllyorsa ilgili yerler tamamen silinecektir.

17. Bayramlarmizdan, festivallerimizden ve kutsal günlerimizden hakaret eder şekilde bahseden her yer, mesela "onların bayramlarmian önce..."67 ya da "Bir Yahudi'nin onların bayram günlerinde onlarla alışveriş yapması yasaktır"68 gibi ifadeler tamamen silinecektir.

\footnotetext{
65 Mişna, Nedarim, 3:11.

66 Yahudi dinî literatüründe Hıristiyanlar için kullanılan en yaygın ifadelerden birisi de arelim (sünnetsizler) şeklindedir.

67 Mişna, Avoda Zara, 1:1.

68 İbn Meymun, Mişne Tora, Hilhot Avoda Zara, 9:1.
} 
18. Yine Kalenda ve Saturnalia gibi açıç̧a yazılan bayram isimlerinin silinmesi gerekmektedir. ${ }^{69}$

19. Keşişler, papazlar, kardinaller, dükler veya papalardan bahseden her yer [İsa] efendimizin gelişinden önceki döneme yönelik anlaşlamayacaksa tamamen silinecektir. ${ }^{70}$

20. [İsa] Efendimizin gelişinden sonraki dönemde yaşayan herhangi bir Yahudi için tsadik (salih), kadoş (mübarek); Yahudi cemaati için de kehila kedoşa (kutsal cemaat) veya edat ha-şem (Tanrı'nın topluluğu) gibi kullanımlar olan her yer silinecektir. Bütün bu işler kavrayış ve bilgi gerektiren sağlam bir tetkik istiyor, hele de avoda zara geçen yerler için.

Domenico, bu listenin sonunda yüzünü Baba, Oğul ve Kutsal Ruh’a dönerek onlardan medet umduğunu belirterek “İsa'nın inancını savunmak için Tanrı benim yardımcım olsun. Karanlıkta giden halk -ki onlar Yahudilerdir- onların gözünü de açsın. Böylece iyi yolu ve ebedi yaşam yolunu görsünler, öyle ki o yol Tanrı'nın Mesihi İsa efendimizin yoludur" ifadelerini kullanmaktadır.

Domenico'nun İbranice kitaplar için listelediği sansür taleplerini üç kategoride ele almak mümkündür. Bunlardan ilki, Hıristiyan inancına yönelik küçük düşürücü ifadelerdir. İkincisi, Yahudilerin yüceltilmesine dair pasajlardır. Üçüncüsü de itikadi anlamda sapkın sayılan görüşlerdir. Domenico, bu ilkelerin fiili uygulamasını yaptığı Sefer ha-Zikuk'ta bu üç türün farklı şekillerde yansıdığı sansürler teklif etmektedir. Bunlardan ilki, kelime silme veya değiştirmedir. Bunlar arasında avoda zara (putperestlik), min (heretik), minim (heretikler), Edom, ${ }^{71}$ meşumad (mürted) gibi kelimeler ilk sıralarda yer almaktadır. Bunlarda genellikle mahak (sil), al ha-mahak (silinmeli), kulo yimahek (hepsi silinecek), mahak ha-kol (tamamını sil), hakol yimahek (hepsi silinecek) ve yimahek le-gamre (tamamen silinecek) gibi ifadeler kullanılmaktadır. Yukarıda listelenen düzenlemeler istikametinde uygulanan bir diğer yöntem de kelime değiştirmedir. Metinlerde geçen ve Hıristiyanlığa işaret ettiği düşünülen avoda zara, goy (Yahudi olmayan), nohri (yabancı), meşumad kelimeleri akum kelimesiyle değiştirilmektedir.

\footnotetext{
69 Bkz. Mişna, Avoda Zara, 1:3.

70 İsa'dan önce Hıristiyanlık olmadığı için burada genel anlamda din adamı türlerinin tamamı kastedilmektedir.

${ }^{71}$ Edom, Filistin'in güneyinde ve Ürdün'de kurulan eski bir krallıktır. Kelime anlamı itibarıyla kırmızı demektir. Esav, kırmızı renkli olarak doğduğu için Edom, Esav'ın sıfatı olarak da kullanılmaktadır. Bkz. Tekvin 25:25. Yahudi dinî literatüründe Edom ve Esav, genellikle Roma İmparatorluğu ve sonrasında da Hıristiyan dünyası için kullanılmaktadır.
} 
Bu yapılırken yimahek ve-yikatev bimkomo (silinecek ve yerine şu yazılacak) veya tsarih le-taken (düzeltilmesi gerek) ifadeleri kullanılmaktadır. ${ }^{72}$

Sansür ilkeleri listesinde 10. maddede görüldüğü üzere bazen fiilin zamanı değiştirilmiştir. "Sünnet derisi iğrençtir" ifadesi Hıristiyanları kastettiği gerekçesiyle geçmiş zaman kipine dönüştürülmüştür. Sefer haZikuk'ta 7 numaralı Yisthak Arama'ya ait Venedik'te basılan Akedat Yitshak isimli eserde böyle bir ifade görülmektedir. ${ }^{73}$ Bazen de yaprağın tamamen yırtılması söz konusudur. Mesela, 313 numaralı Sefer Neviim Aharonim im Peruş Abarbanel Defus Soncino künyeli eser için "Bu eserin sıkı bir sansüre ihtiyacı var, zira içerisinde inancımıza ters bir sürü şey var. Özellikle Edom ismini zikrettiği yerlerde ve bizim din bilginlerimizle polemik yaptığı her konuda müellif bizim inancımızı kastediyor, bu tür yerlerde ilgili yaprak tamamen yırtılıp atılmalıdır" ifadelerine yer vermektedir. ${ }^{74}$ Bazı düzeltme taleplerinde ise ilgili pasaja özel önem gösterilmesi ve kemal-i ciddiyetle ele alınması gerektiğine dair not bulunmaktadır. $\mathrm{Bu}$ tavsiye edilirken genellikle tsarih iyun (tetkik lazım), tsarih iyun gadol (sıkı tetkik lazım), tsarih iyun harbe (çok tetkik lazım), tsarih iyun heytev be-kulo (tamamında iyi bir tetkik gerek), ha-kol be-iyun yimahek (tamamı tetkik edilerek silinecek) ve ha-kol be-iyun nimrats (tamamı sağlam tetkikten geçecek) gibi ifadeler kullanılmaktadır. ${ }^{75}$ Bunların dışında bazı yerlerde düzeltme gerekçelerini yazdığı, bazı yerlerde metnin sorunlu olduğunu ifade ettiği halde herhangi bir düzeltme yapmadığı̆, bazı yerlerde de matbaacının baskıda bazı yerleri düzeltmek isterken pasajı daha da sorunlu hale getirdiğini belirtmektedir. ${ }^{76}$

Domenico, Sefer ha-Zikuk'ta kitapların isimlerini ve genellikle basım yerlerini başlık olarak yazmaktadır. Listelerde müellif ismi nadiren yer almaktadır. Bir eserin farklı yerlerdeki (Mantua, Venedik, Roma, Hamburg, İstanbul gibi) bütün baskılarında sansür gerekiyorsa Domenico bunu zikuk kolel (tam sansür) veya sadece kolel (tam) olarak ifade etmektedir. Eser hacimliyse kovets gadol (büyük mecmua) veya sadece gadol (büyük), kısaysa kovets revia (çeyrek mecmua) veya kovets katan (küçük mecmua) ifadelerini kullanmaktadır. Sorun olmayan kitaplar için eyn davar (bir şey yok) veya uzun haliyle eyn davar ma la-hagiah (düzeltilecek bir şey yok) ifadeleri kullanılmaktadır. ${ }^{77}$

\footnotetext{
72 Prebor, "Sefer ha-Zikuk şel Dominiko Yeruşalmî”, 18-19.

73 Prebor, "Sefer ha-Zikuk şel Dominiko Yeruşalmî", 64.

74 Prebor, "Sefer ha-Zikuk şel Dominiko Yeruşalmî", 222.

75 Prebor, "Sefer ha-Zikuk şel Dominiko Yeruşalmî", 19, 127.

76 Prebor, "Sefer ha-Zikuk şel Dominiko Yeruşalmî", 20.

77 Prebor, "Sefer ha-Zikuk şel Dominiko Yeruşalmî”, 12-13; Prebor, "Sefer ha-Zikuk keMakor Bibliyografî, 65; Porges, “Der hebräische Index expurgatorius”, 289.
} 
Sefer ha-Zikuk'taki eserler türlerine göre ayrıldığında en fazla sansüre tabi tutulanların Tanah tefsirleri (\%17-18), halaha kitapları (\%16), ahlak literatürü (\%10) ve felsefi eserler (\%8) olduğu görülmektedir. En az oran ise edebiyat kitapları, litürji, Mişna ve Talmud şerhleri, gramer kitaplarında yer almaktadır. Listedeki eserlerin \%70'i İtalya'da, bunların yaklaşık \%46'sı da Venedik'te basılmıştır. Sefer ha-Zikuk'taki kitaplardan 51 tanesi İstanbul'da, 29 tanesi Selanik'te, 2 tanesi de Safed'de basılan eserlerdir. Listedeki eserlerin çoğunun Domenico'nun yaşadığı süre zarfında basıldığı görülmektedir. Listede en eski tarihli eser 1477 yılına aittir. En son tarihli eser ise 1612 yllına aittir. Eserde incelenen kitapların yaklaşık yarısı 15001600 yllları arasıyla tarihlendirilmektedir. Bu iki tarih arasında bazı araştırmacılara göre 2189, bazılarına göre 3294 farklı İbranice eser basılmıştır. Bu durumda Sefer ha-Zikuk'ta sadece \%15-20'lik bir oranın sansür için elden geçirildiği anlaşılmaktadır. Yine 49 kitapta (yaklaşık \%10) baskı tarihi yer almamaktadır. Bu tür kitaplarda genellikle kolel yazılarak bütün farklı baskılarında aynı ifadelerin silinmesi gerektiği belirtilmektedir. ${ }^{78}$ Sefer ha-Zikuk'taki kitap listeleri, basım yerleri İbrani kitap bibliyografyası açısından çok değerli bilgiler vermektedir. Mesela, bu liste sayesinde emin olunmayan bazı bilgiler teyit edilmekte, daha önce orada basıldığına dair bir bilgi olmayan kitapların belirli bir şehirde ve hangi tarihte basıldığı da öğrenilmiş olmaktadır. ${ }^{79}$

Sefer ha-Zikuk'un sonraki dönemlerdeki etkisiyle ilgili farklı görüşler ortaya atılmıştır. Bazı araştırmacılar sonraki sansürcülerin Domenico'nun eserini çok az kullandıklarını, bazı araştırmacılar da hiç kullanmadıklarını ve kafalarına göre uygun gördükleri şekilde sansür yaptıklarını iddia etmektedirler. 1738 tarihli bir dilekçede Roma Yahudi cemaati, engizisyon kurumundan kendilerinden alınan kitapların iadesini talep etmiştir. Bu dilekçede kitapların Domenico Yeruşalmî'nin Sefer ha-Zikuk adlı eseri çerçevesinde sansürden geçirildiği ifade edilmektedir. Bu dilekçeden sonra bir başka dilekçede bütün kitapların iade edilmediği, Sefer ha-Zikuk ışığında kitapların gözden geçirildiği, yapılan düzenlemeler gereğince kitapların iade edilmesini bekledikleri, gerekiyorsa yeniden gözden geçirildikten

78 Baruchson-Arbib \& Prebor, "Sefer Ha-Ziquq (An Index of Forbidden Hebrew Books)", 13-17; Prebor, "Sefer ha-Zikuk ke-Makor Bibliyografi”, 66-68; Prebor, "Sefer ha-Zikuk şel Dominiko Yeruşalmî”, 14-15.

79 Sefer ha-Zikuk'un İbrani kitap bibliyografyasındaki yeri ve önemi için detaylı inceleme için bkz. Prebor, "Sefer ha-Zikuk ke-Makor Bibliyografi”, 70-80. Prebor, Domenico'nun bu eserde işaret ettiği yerleri ilgili baskılarda kontrol etmiş ve neticede Domenico'nun çok titiz ve hassas çalıştığını, küçük birkaç hata dışında kelimesi kelimesine işçilik yaptığını belirtmektedir. Bkz. Prebor, "Sefer ha-Zikuk keMakor Bibliyografî", 66. 
sonra iade edilmesini bekledikleri ifade edilmektedir. Yine 18. asrın ortalarında Roma'daki engizisyon kurumunda İbrani kitapların sansüründen sorumlu olan Giovanni Antonio Costanzi, her yerde İbranice kitapları sansürleyecek İbranice ve Yahudi dinî literatürü konusunda yetkin kişiler bulunmadığını, bu sebeple Sefer ha-Zikuk adında bir kitap hazırlandığını, bu çalışmada 450 kitabın listelendiği ve her kitabın yanında silinmesi veya değiştirilmesi gereken paragraflarla ilgili bilgiler verildiğini belirtmektedir. ${ }^{80}$

Baruchson-Arbib ve Prebor, sansürden geçmiş 300 eseri inceleyerek sansürlenen kitaplarla Sefer ha-Zikuk'taki talepler arasındaki oranı ortaya koymaya çalışmışlardır. 300 eserden 154 tanesinde, sansürden geçirildiğine dair imza olmasına rağmen kitabın içerisinde en ufak bir sansür emaresi görülmemiştir. Sefer ha-Zikuk'ta ise bu 154, kitaptan sadece 42 tanesi için "sansürlük bir durum yoktur" ifadesi bulunmaktadır. Bu durumda, sansüre tabi olduğu ve sansürcüler tarafından gözden geçirildiği halde, 112 kitaba en ufak bir müdahalede bulunulmamıştır. 300 kitaptan Sefer ha-Zikuk'taki talep edilen düzeltmelere uyma oranı sadece \%33 çıkmıştır. İlginç bir şekilde Domenico Yeruşalmî'nin sansüründen geçen 34 kitap incelendiğinde kendisi de Sefer ha-Zikuk'ta sansürlenmesi gerektiğini söylediği yerlerin sadece \%32'sini sansüre tabi tutmuştur. ${ }^{81}$

Araştırmacılar arasında bu durum farklı şekillerde açıklanmaktadır. Bazı araştırmacılar, Yahudilerin sansürcülere rüşvet vererek kitaplarını sansürden koruduklarını belirtmektedirler. Bunun haricinde Kilise içerisinde de bazı sansürcülerin işlerini iyi yapmadıklarına, gevşek ve ilgisiz davrandıklarına, konuya ehemmiyet göstermediklerine, yeterli donanıma sahip olmadıklarına ve Yahudilerden para aldıklarına dair şikâyetler yer almaktadır. Nitekim 1556 yılında Papa IV. Paul, sansür işlerinde görevli Yahudi dönmesi Giacomo Geraldino'yu Yahudilerden rüşvet aldığı iddiasından ötürü sansür görevinden azletmiştir. ${ }^{82}$ Baruchson-Arbib ve Prebor ise sansür için binlerce kitabın elden geçirilmesi gerektiğini, her sayfanın ve satırın tek tek kontrol edilmesine ihtiyaç duyulduğunu, Sefer ha-Zikuk'ta doğrudan ilgili paragraflar yer alsa bile bunun çok zahmetli bir

8o Popper, The Censorship of Hebrew Books, 119; Baruchson-Arbib \& Prebor, "Sefer HaZiquq (An Index of Forbidden Hebrew Books)", 10-11.

81 Baruchson-Arbib \& Prebor, "Sefer Ha-Ziquq (An Index of Forbidden Hebrew Books)", 16-17, 20-21; Prebor, "Sefer ha-Zikuk şel Dominiko Yeruşalmî”, 21.

82 Popper, The Censorship of Hebrew Books, 40; van Boxel, "Hebrew Books and Censorship in Sixteenth-Century Italy", 80; Offenberg, "The Censorship of Hebrew Books in Sixteenth-Century Italy", 19; Sonne, Expurgation of Hebrew Books, 206. Elimizdeki kayıtlara göre İbrani kitaplarına sansür işinde istihdam edilen kişi Giacomo Geraldino'dur. 
iş olmasından ötürü ihmallerin ortaya çıktığını öne sürmektedirler. Sansürcülerin yaptığı sansürlerde en yüksek oranlar edebiyat metinleri (\%66), bilim ve tarih kitaplarıdır (\%48). Bu metinler aynı zamanda en az sansür isteyen metinler olduğu için sansürcüler açısından sansüre en fazla riayet edilen metinler olarak karşımıza çıkan eserlerdir. İçerisinde çok fazla sansür gerektiren eserlerde ise gerekli olan sansür ile fiilî olarak uygulanan arasında oran gittikçe düşmektedir. Yahudi dönmeler bile olsalar özellikle Kabala metinleri sansürcüler açısından da zorluk teşkil etmiştir. Nitekim yapılan incelemede Kabala metinlerinde Sefer ha-Zikuk'ta talep edilen sansürün sadece \%11'i uygulanmıştır. ${ }^{83}$

\section{Sonuç}

Üç farklı coğrafyada iki farklı dinî geleneği hayat hikâyesinde birleştiren Domenico Yeruşalmî, gerek İstanbul izlenimlerine dair kitabıyla dönemin İstanbul'u hakkında gerek otobiyografisiyle gerekse sansür faaliyetleriyle farklı alanlarda çok değerli bilgileri miras bırakmıştır. Yahudi bir âlimin Hıristiyan olarak Papalığın hizmetinde sansürcülük görevinde bulunması, eski dindaşlarına yönelik misyonerlik faaliyetleri yapması, onların Hıristiyanlığı benimsemeleri için İbraniceye çeviriler yapması din değiştirmedeki ciddiyetinin bir göstergesi kabul edilebilir.

Sefer ha-Zikuk adlı eseriyle tarihe önemli bir kayıt düşen Domenico, hiç şüphesiz İbranice kitapların sansüründe tarihinin en önemli isimlerinden birisidir. Eserde listelediği kitaplarda silinmesi gereken yerler ve temel sansür ilkeleri o dönemler itibarıyla aynı zamanda Yahudi-Hıristiyan polemiklerine dair son derece değerli bilgiler edinmemize imkân sağlamaktadır. Bir diğer ifadeyle Yahudi dinî literatüründe Hıristiyanlık açısından sakıncalı görülen ifade ve pasajların listesinin her bir kitap özelinde listelenmesi, konunun canlılığını göstermesi ve birinci elden kaynaklık teşkil etmesi açısından son derece önem arz etmektedir. Diğer taraftan Talmud gibi Yahudiliğin en temel metinlerinden birinin Sefer haZikuk'ta yer alamayacak kadar tehlikeli görülmesi de Talmud'un Kilise tarafından nasıl algılandığını göstermektedir.

Domenico Yeruşalmî, Sefer ha-Zikuk'ta bıkmadan usanmadan Yahudi dinî literatürünü listelemiş, her bir sayfa ve satırındaki sıkıntılı ifadeleri belirtmiştir. İlginç olan husus şu ki Domenico, Sefer ha-Zikuk'taki bu gayret ve ciddiyetini sansür faaliyetleri sırasında göstermemiştir. Her ne kadar sansürcülere bir el kitabı sunmuş olsa da Domenico'nun imzasını taşıyan ve

83 Baruchson-Arbib \& Prebor, "Sefer Ha-Ziquq (An Index of Forbidden Hebrew Books)", 16-22. 
sansürden geçirilmiş eserler incelendiğinde bazısında çok kısmi düzenlemelerin yapıldığı, birçoğuna ise hiç müdahale edilmediği görülmektedir. Bir diğer ifadeyle Domenico'nun kendisi, Sefer ha-Zikuk'ta listelediği hususlara fazla riayet etmemiştir.

\section{Teşekkür}

Yazar, makaleyi okuyarak önemli düzeltme ve tashihler teklif eden Dr. Tolga Savaş Altınel, Dr. Abdullah Altuncu, Arş. Gör. Fatma Seda Şengül, Fatıma Betül Taş, Büşra Şahin ve Kübra Güneş’e teşekkür eder.

\section{Kaynakça}

Austin, Michael. Domenico's Istanbul. Londra: E.J.W. Gibb Memorial Trust, 2001.

Shifra Baruchson-Arbib \& Gila Prebor. "Sefer Ha-Ziquq (An Index of Forbidden Hebrew Books)-The Book's use and its influence on Hebrew Printing”. La Bibliofilia 109:1 (2007): 3-31.

Blokland, Dina. The Gospel according to Matthew in the Translation of Domenico of Jerusalem, a Jew who Became a Christian. Doktora Tezi, Kudüs: Kudüs İbrani Üniversitesi, 2019.

Boxel, Piet van. "Hebrew Books and Censorship in Sixteenth-Century Italy". Jewish Books and their Readers, ed. Scott Mandelbrote \& Joanna Weinberg, Leiden: Brill, 2016, 75-99.

Carmilly-Weinberger, Moshe. "External and Internal Censorship of Hebrew Books". Jewish Book Annual 28 (1970): 9-16.

Corcos, David \& Getzel Kressel. "Bibas”. Encyclopedia Judaica, MI: Thomson Gale, 2007, 3: 571-572.

Domenico Hierosolimitano. Bir Yahudi Doktorun Harem, Saray ve İstanbul Hatıraları. Çev. Esma Selçuk Demir, İstanbul: Yeditepe Yayınevi, 2017.

Finkelstein, Louis. Jewish Self-Government in the Middle Ages. New York: The Jewish Publication Society Press, 1924.

Francesconi, Federica. "This passage can also be read differently ..." How Jews and Christians censored Hebrew texts in early modern Modena". Jewish History 26 (2012): 139-160.

Guidi, Ignazio. “Domenico Gerosolimitano”. Festschrift zum siebzigsten Geburtstage A. Berliner's, ed. A. Freimann \& M. Hildesheimer, Frankfurt, 1903, 176-179.

Horovitz, Marcus. Die Frankfurter Rabbinerversammlung vom Jahre 1603. Frankfurt: M. Slobotzky, 1897.

Ioly Zorattini, Pier Cesare. “Domenico Gerosolimitano a Venezia”. Sefarad 58 (1998): 107-115.

Marcus, Jacob Rader \& Marc Saperstein. The Jews in Christian Europe: A Source Book 315-1791. Pittsburgh: Hebrew Union College Press, 2015.

Offenberg, Adri K., "The Censorship of Hebrew Books in Sixteenth-Century Italy", Against the Law: Crime, Sharp Practice and the Control of Print, ed. Robin Myers, 
Michael Harris, and Giles Mandelbrote, Oak Knoll Press, New Castle, 2004, ss. 24-25.

Popper, William. The Censorship of Hebrew Books. Knickerbocker Press, New York 1899.

Porges, Nathan. “Censorship of Hebrew Books". Jewish Encyclopedia, New York: Funk and Wagnalls, 1903, 3: 64,2-650.

Porges, Nathan. "Der Hebräische Index Expurgatorius”. Festschrift zum Siebzigsten Geburtstage A. Berliner's, ed. A. Freimann ve M. Hildesheimer, Frankfurt: J. Kaufmann, 1903, 273-295.

Prebor, Gila. "Domenico Yerushalmi: His Life, Writings and Work as a Censor". Materia Giudaica: Rivista dell'Associazione Italiana per lo Studio del Giudaismo XV/XVI (2010/201): 467-481.

Prebor, Gila. "mi-Yeruşalayim le-Venetsiya: Hayav şel Dominiko Yeruşalmî, Hiburav ve-Peiluto ke-Tsentsor”. Pe'amim 111-112 (2007): 215-242.

Prebor, Gila. “Sefer ha-Zikuk ke-Makor Bibliyografi”. Aley Sefer 23 (2013): 63-80.

Prebor, Gila. "Sefer ha-Zikuk şel Dominiko Yeruşalmî”. Italia 18 (2008): 7-302.

Putnam, George Haven. The Censorship of the Church of Rome. New York \& Londra: The Kneckerbocker Press, 1906-1907.

Raz-Krakotzkin, Amnon. "Censorship, Editing, and the Reshaping of Jewish Identity: the Catholic Church and Hebrew Literature in the Sixteenth Century". Hebraica Veritas? Christian Hebraists and the Study of Judaism in Early Modern Europe, ed. Allison P. Coudert \& Jeffrey S. Shoulson, Philadelphia: University of Pennsylvania Press, 2004, 125-155.

Raz-Krakotzkin, Amnon. "The Censor as a Mediator: Printing, Censorship and the Shaping of Hebrew Literature". The Roman Inquisition, the Index and the Jews, ed. Stephan Wendehorst, Brill, Leiden 2004, ss. 35-57.

Raz-Krakotzkin, Amnon. ha-Tsentsor, ha-Orehve-ha-Tekst: ha-Tsentsura ha-Katolit veha-Defus ha-İvrî be-Mea ha-Şeş Esra. Kudüs: Magnes Press, 2005.

Raz-Krakotzkin, Amnon. The Censor, the Editor, and the Text: The Catholic Church and the Shaping of the Jewish Canon in the Sixteenth Century. Philadelphia: University of Pennsylvania Press, 2007.

Rostagno, Lucia. "Note su Domenico Gerosolimitano. A Proposito del Recente Saggio di M. Austin. Parte I". Rivista degli Studi Orientali 76 (2002): 231-262.

Sacerdote, Gustavo. I Codici Ebraici della Pia Casa dei Neofiti in Roma. Roma: Tipografia della R. Accademia dei Lincei, 1893.

Simonsohn, Shlomo. "Sfarim ve-Sifriyot şel Yehudey Mantuva, 1595". Kiryat Sefer 37:1 (1961): 103-122.

Sonne, Isaiah. Expurgation of Hebrew Books-the Work of Jewish Scholars: A Contribution to the History of the Censorship of Hebrew Books in Italy in the Sixteenth Century. New York: New York Public Library, 1943.

Stow, Kenneth R. "The Burning of the Talmud in 1553, in the Light of Sixteenth Century Catholic Attitudes Toward the Talmud". Bibliotheque d'Humanisme et Renaissance 34:3 (1972): 435-459.

Stow, Kenneth. The Jews in Rome. Leiden: Brill, 1997.

Wagenseil, Johann Christoph. Tela ignea Satanae. Altdorf, 1681. 


\section{Internet Kaynakları:}

Biblioteca Apostolica Vaticana, “Neofiti.33”. Erişim: 3.11.2021, http://www.mss.vatlib.it/guii/console? service=shortDetail\&cid=255249.

Biblioteca Apostolica Vaticana, “Neofiti.34". Erişim: 3.11.2021, http://www.mss.vatlib.it/guii/console? service=shortDetail\&cid=195872.

Biblioteca Apostolica Vaticana, "Neofiti.36". Erişim: 3.11.2021, http://www.mss.vatlib.it/guii/console? service=shortDetail\&cid=19594,6. 